\title{
PERANCANGAN SISTEM INFORMASI PENGELOLAAN ADMINISTRASI KEUANGAN MADRASAH ALIYAH MUHAMMADIYAH BOARDING SCHOOL KOTA METRO
}

\author{
Nurul Hidayati ${ }^{(1)}$ Arif Hidayat ${ }^{(2)}$ \\ Jurusan Ilmu Komputer, Fakultas Ilmu Komputer,Universitas Muhammadiyah Metro \\ Jl.Gatot Subroto No.100 Yosodadi Kota Metro, Telpon :(0725)42445-Fax(0725)42454 \\ E-mail: androidarifhidayat@gmail.com
}

\begin{abstract}
Abstrak
Tugas Akhir ini merupakan hasil analisis dan observasi yang penulis lakukan terhadap pengolahan data pembayaran SPP yang sedang berjalan dan hasil perancangan pengolahan data pembayaran SPP yang baru pada Madrasah Aliyah Muhammadiyah Boarding School Kota Metro. Penelitian menggunakan metode pengamatan, observasi dan wawancara. Sedangkan untuk metode pengembangan aplikasi menggunakan Data Flow Diagram, Entity Relationship Diagram dan Flowchart. Software pendukung dalam pembuatan aplikasi pengolahan data yaitu Dreamweaver Cs6 dan database yang digunakan adalah MySQL (XAMPP).Dengan adanya Perancangan sistem informasi pengelolaan Administrasi Keuangan Madrasah Aliyah Muhammadiyah Boarding School diharapkan dapat mengurangi terjadinya kesalahan dalam memasukkan data dan pembuatan laporan dalam proses pengolahan data pembayaran SPP.
\end{abstract}

Kata Kunci: Sistem Informasi pengelolaan,administrasi keuangan, pembayaran spp. Madrasah Aliyah Muhammadiyah Boarding school Kota Metro. Laporan Data pembayaran SPP MA dan Pondok.

\section{PENDAHULUAN}

SMP Muhammadiyah Ahmad Dahlan adalah sekolah yang menerapkan Pendidikan Holistic berbasis nilai islam, dengan terapan pembelajaran Full Day School, mencetak peserta didik yang tidak hanya unggul dalam bidang akademik tetapi juga bidang non Akademik, dengan terapan sistem pembelajaran peminatan, pembelajaran sesuai dengan kompetensi masingmasing siswa, dan pendekatan berbasis kompetensi anak, sekolah yang beralamat di JL. AR. Prawiranegara, Mulyojati, Metro Barat, Kota Metro ini sudah berdiri sejak tanggal 05 Maret 2015 setelah peletakan batu pertama oleh Prof. Dr. KH. Muhammad Sirajuddin Syamsuddin, MA Ketua Umum Pimpinan Pusat Muhammadiyah periode 2005-2010 dan 20102015. Dalam meningkatkan kualitas pelayanan dan pembelajaran tentunya SMPMu Ahmad Dahlan telah bersikap Ikhlas dan bersungguhsungguh dalam mengembangkan Amanah persyarikatan dimana SMP Muhammadiyah Ahmad Dahlan sebagai basis dakwah dibidang pendidikan, Allah Jalla wa 'Alaa berfirman

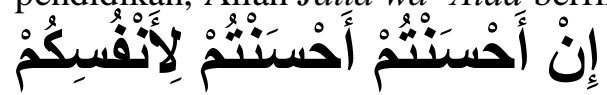

"Jika kalian berbuat baik, sesungguhnya kalian berbuat baik bagi diri kalian sendiri”, (QS. AlIsra:7).

SMP Muhammadiyah Ahmad Dahlan sejak berdirinya pada tahun 2015 telah banyak sekali menorehkan prestasi baik di bidang akademik dan non akademik, namun dalam hal pengolahan uang tabungan berupa nilai uang dan pendataanya menggunakan buku besar dan media cetak berupa buku profil sekolah yang dilampirkan list data siswa yang menabung, dan 
pemasukan data uang siswa yang dalam pengelolaannya tidak dioptimalkan dengan pemanfaatan media elektronik sehingga terkesan tidak transparan, menyulitkan siswa atau siswi dalam melihat perkembangan teknologi dalam bidang elektronik. Dengan berkembangnya ilmu pengetahuan dan teknologi sekarang ini sangat berpengaruh terhadap aspek kehidupan, salah satunya dalam bidang informasi yaitu dengan munculnya komputer sebagai alat bantu dalam melakukan pengolahan data dan pembuatan laporan. Komputer merupakan salah satu alat bantu bagi manusia dalam melakukan pengolahan data baik bidang pendidikan, kesehatan, instansi pemerintah maupun badan usaha lainnya. Kemajuan Ilmu Pengetahuan dan Teknologi (IPTEK) yang mengakibatkan banyak perubahan disegala bidang, salah satunya di bidang pengolahan data tabungan dalam pencatatan masih menggunakan buku besar, akibatnya data tabungan tidak berurutan, dan besaran tabungan antara buku besar dengan aplikasi excel tidak sama, akibatnya ada selisih uang yang membingungkan petugas tabungan pada SMP Muhammadiyah Ahmad Dahlan. Mau tidak mau bagian pengolahan data tabungan ini harus menangani masalah para siswa/siswi. Untuk itu harus adanya sistem kerja yang praktis dan efisien sehingga bisa mempelancar kegiatan di Kantor tersebut. Dalam hal ini dibutuhkan tenaga yang profesional dengan pengertian mampu merubah suatu sistem kerja sehinga bisa menghasilkan sistem yang aman dan efisien, mungkin untuk bisa lebih mudah dan mempelancar suatu pekerjaan yang tentunya sesuai dengna keahlian dan kemampuan yang dimilkinya. SMP Muhammadiyah Ahmad Dahlan berupaya untuk menunjang kerjanya dengan sistem informasi sehingga memberikan sistem informasi data keuangan, adanya komputer tetapi masih meggunakan cara-cara yang menual.

Dengan sistem ini diperlukan banyak pegawai dan menghabiskan waktu yang lama untuk menyelesaikan suatu tugas, khususnya dibidang pengolahan data tabungan. Bertitik tolak dari masalah diatas maka SMP Muhammadiyah Ahmad Dahlan dirasa perlu meggunakan program khusus sebagai alat pengolahan data tabungan siswa agar informasi yang dibutuhkan dapat segera diperoleh dan diproses dengan efisien dan efektif. Dengan demikian hasil yang diperoleh akan sesuai dengan yang diharapkan. Dengan adanya komputer sebagai alat bantu dalam pengolahan data maka penulis merasa tertarik untuk membuat tugas akhir dengan judul "Perancangan Aplikasi Pengolahan Data Tabungan Siswa Berbasis Delphi pada SMP Muhammadiyah Ahmad Dahlan". Permasalahan yang ditemukan selama Kuliah Kerja Praktek (KKP) di SMP Muhammadiyah Ahmad Dahlan adalah belum maksimalnya pemanfaatan media elektronik sebagai pembantu sistem kerja, akibatnya stap administrasi kesulitan dalam menangani siswa atau siswi yang hendak menabung. Berdasarkan kebutuhan dan permasalahannya maka SMP Muhammadiyah Ahmad Dahlan sangat memerlukan sebuah terobosan perancangan sistem pengolahan data tabungan siswa, dapat membantu perkembanga sistem komputerisasi, dalam hal ini perlu ditambahkan layanan pengolah antara stap administrasi dan siswa atau siswi secara cepat, sehingga bagi siswa atau siswi dapat menabung dengan baik dan tertip tidak menimbulkan kegaduhan yang tidak diinginkan.

Terobosan yang dimaksud tentunya dapat mempermudah siswa atau siswi dalam menabung melalui aplikasi tersebut, sehingga tentunya sangat bermanfaat bagi petugas administrasi khususnya petugas tabungan, seperti sabda rasullullah Shallallahu'alaihi Wasallam pernah bersabda bersabda :

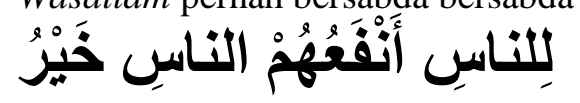

"Sebaik Baik Manusia Adalah Yang Paling Bermanfaat Bagi Orang Lain”, (HR.Ahmad).

Berdasarkan latar belakang dan permasalahan tersebut diatas maka SMP Muhammadiyah Ahmad Dahlan sangat membutuhkan sebuah terobosan aplikasi yang menjawab permasalahan-permasalahan tersebut yaitu "PERANCANGAN APLIKASI PENGOLAHAN DATA TABUNGAN SISWA BERBASIS DELPHI PADA SMP MUHAMMADIYAH AHMAD DAHLAN KOTA METRO”.

\section{LANDASAN TEORI}




\subsection{Definisi Perancangan}

Menurut Rizky (2014 : 139) yang dikutip Saputra dkk(2014:129) "perancangan adalah sebuah proses untuk mendefenisikan suatu yang akan dikerjakan dengan mengunakan teknik yang bervariasi serta didalam melibatkan deskripsi mengenai arsitektur serta detail komponen dan juga keterbatasan yang akan dialami dalam proses pengerjaanya".

Sedangkan Menurut prahasta (2014 : 129) "perancangan merupakan suatu proses pengunaan berbagai prinsip dan teknik untuk tujuan - tujuan pendefenisian suatu perangkat, proses, atau sistem hingga ketingkat detail tertentu yang memungkinkan realisasi (implementasi) bentuk fisiknya (termasuk aplikasi perangkat lunak)". Dapat disimpulkan bahwa perancangan adalah penentuan proses pembangunan, perencanaan dan pembuatan sketsa atau pengaturan suatu untuk menunjukan suatu hal yang akan di buat, dengan tujuan mengurangi resiko ketidak pastian yang lebih tinggi. Berdasarkan definisi para ahli, penulis menyimpulkan bahwa perancangan adalah sebuah proses untuk pembuatan dan pembangunan,perencanaan yang berguna untuk mengurangi sebuah resiko ketidak pastian.

\subsection{Definisi Sistem}

Menurut Hartono (2005:1) Sistem adalah "Kumpulan dari elemen-elemen yang berinteraksi untuk mencapai suatu tujuan tertentu. Sistem ini menggambarkan suatu kejadian-kejadian dan kesatuan yang nyata, seperti tempat, benda dan orang-orang yang betul-betul ada dan terjadi".

Menurut Jogiyanto (2012:3) sistem adalah "Sebagai suatu kumpulan komponen yang berinteraksi membentuk suatu kesatuan dan keutuhan yang komplek ditingkat tertentu untuk mengejar tujuan yang umum".
Berdasarkan definisi para ahli, penulis menyimpulkan bahwa perancangan sistem adalah satu kesatuan komponen yang berkumpul untuk mencapai sebuah tujuan tertentu

\subsection{Definis Informasi}

Menurut Laudon yang dikutip oleh kadir (2009:3) Informasi adalah "Data yang telah diolah menjadi bentuk yang bermakna dan berguna bagi manusia". Menurut Davis yang dikutip oleh kadir (2009:3) Informasiadalah: "Data yang telah diolah menjadi sebuah bentuk yang berarti bagi penerimanya dan bermanfaat dalam pengembalian keputusan saat ini atau saat mendatang".

Berdasarkan definisi para ahli, penulis menyimpulkan bahwa Informasi adalah sekumpulan Data yang telah melalui proses sehingga menghasilkan sebuah informasi yang berguna bagi manusia.

Definisi Sistem Informasi

Menurut Alter (2009:7) yang dikutip oleh kadir sistem informasi adalah "kombinasi antara prosedur kerja, informasi, orang dan teknologi informasi yang diorganisasikan untuk mencapa tujuan dalam sebuah organisasi".

Sistem informasi adalah teknologi informasi yang diorganisasikan untuk mencapai tujuan dalam sebuah organisasi (Kadir, 2009). Secara teknis sitem informasi dapat didefenisasikan sebagai kumpulan komponen yang saling berhubungan, mengumpulkan, memproses, menyimpan dan mendistribusikan informasi untuk menunjang pengambilan keputusan dan pengawasan dalam suatu organisasi (Laudon, K C dan Laudon, J.P, 2007:27).

Penulis dapat menarik kesimpulan dari definisi para ahli diatas, bahwa sistem informasi adalah: Sistem informasi adalah suatu sistem yang menyediakan informasi yang terdiri dari komponen-komponen dalam organisasi yang berhubungan dengan proses penciptaan aliran informasi. 


\subsection{Definisi Administrasi Keuangan}

Administrasi Keuangan adalah suatu kegiatan perencanaan penganggaran, pemeriksaan, pengelolaan, pengendalian, pencarian dan penyimpanan dana yang dimiliki oleh organisasi atau perusahaan. Menurut Betha (2014 : 5) yang dikutip Kumalasari dkk(2014:5) Administrasi Keuangan adalah Sebagai semua aktivitas perusahaan dengan usaha-usaha mendapatkan dana perusahaan serta usaha untuk menggunakan dan mengalokasikan dana tersebut secara efisien.

Berdasarkan definisi para ahli, penulis menyimpulkan bahwa perancangan sistem informasi pengelolan administrasi keuangan adalah suatu sistem yang dapat mengolah sebuah informasi data-data keuangan secara komputerisasi.

\subsection{Definisi SPP(Sumbangan Pembinaan Pendidikan)}

SPP(Sumbangan Pembinaan Pendidikan) adalah menurut kamus besar Bahasa Indonesia SPP ada beberapa singkatan yaitu antara lain 1. Surat Persetujuan Pembayaran 2. Sumbangan Pembinaan Pendidikan 3. Surat Perjanjian Penerbitan Namun jika ada hubungannya dengan pendidikan atau sekolah, berarti SPP itu sendiri mengambil definisi no.2 dan bisa diartikan bahwa SPP adalah Sumbangan berupa dana untuk pembinaan pendidikan yang berada dalam suatu instansi pendidikan.

\subsection{Definisi Hypertext Prepocessor (PHP)}

Menurut Nugroho (2005:369) PHP adalah program aplikasi yang bersifat Server Side, artinya hanya dapat berjalan pada sisi server saja dan tidak dapat berfungsi tanpa adanya sebuah server didalamnya. Menurut Anamisa (2011:114) PHP adalah skrip bersifat server-side yang ditambahkan kedalam HTML. Berdasarkan Definisi Para Ahli penulis menyimpulkan PHP adalah sebuah bahasa pemrograman yang hanya dapat diakses dengan bantuan web server perangkat lunak yang memberikan layanan atau service kepada client untuk menerima request HTTP maupun HTTPS dari client yang dikenal. Client yang dimaksud adalah web browser (semisal: Internet Explorer, Google Chrome, Mozilla Firefox).

\subsection{Definisi CSS( Cascading Style Sheet)}

Definisi CSS Menurut Anamisa (2011:47)"CSS adalah kumpulan kode -kode yang berurutan dan saling berhubungan untuk mengatur format atau tampilan suatu halama HTML

2.8 Definisi Hypertext Language (HTML) Definisi HTML menurut Anamisa (2011:13) "HTML adalah file text murni yang dapat dibuat dengan editor teks sembarang".

\subsection{Definisi XAMPP}

Menurut Nugroho (2014 : 23) yang dikutip Hendrianto(2014:59) XAMPP merupakan merupakan paket php berbasis open source yang dikembangkan oleh sebuah komunitas Open Source. Dengan menggunakan XAMPP kita tidak perlu lagi melakukan penginstalan program yang lain karena semua kebutuhan telah disediakan oleh XAMPP. Beberapa pakat yang telah disediakan adalah Apache, MySql, Php, Filezila, dan Phpmyadmin.

Beberapa bagian penting pada program XAMPP, yang sering digunakan pada umumnya adalah sebagai berikut:

htdoc adalah folder tempat meletakkan berkas-berkas yang akan dijalankan, seperti berkas PHP, HTML, CMS dan skrip lain.

phpMyAdmin merupakan bagian untuk mengelola basis data MySQL yang ada dikomputer.

Kontrol Panel yang berfungsi untuk mengelola layanan (service) XAMPP. 
Seperti menghentikan (stop) layanan, ataupun memulai (start).

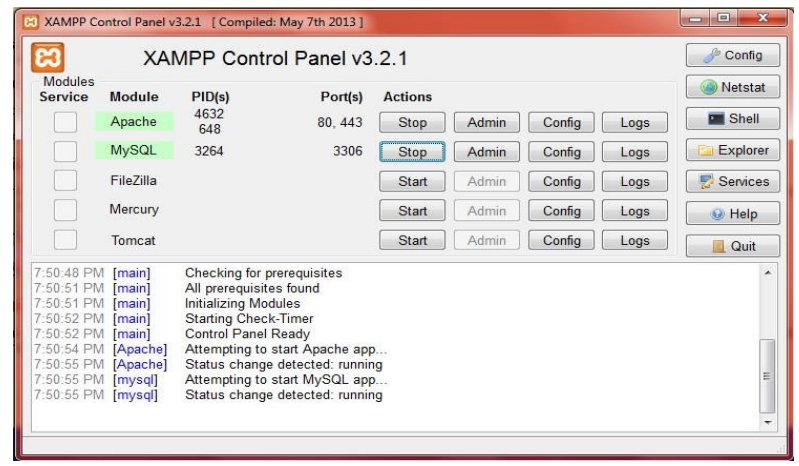

Gambar 2.1 Tampilan XAMPP

(Sumber: XAMPP Control Panel v3.2.1)

PhpMyAdmin adalah salah satu aplikasi berbasis GUI (graphical user interface) yang digunakan untuk mengelola database MySQL. Aplikasi ini berbasis web.

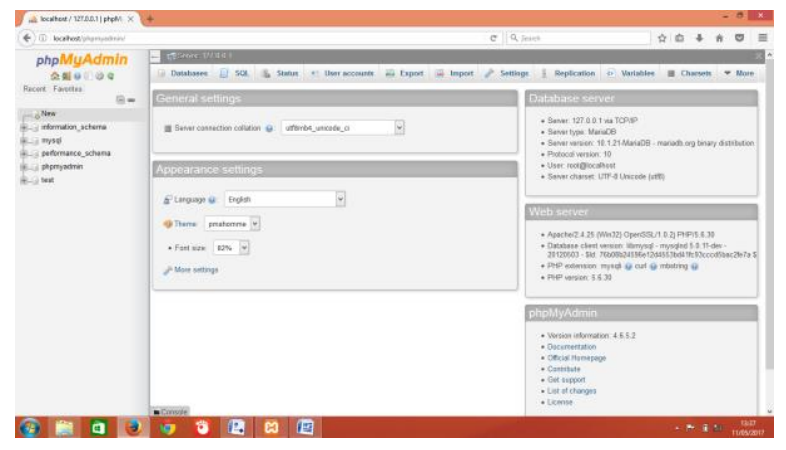

Gambar 2.2 Tampilan PhpMyAdmin dibrowser

(Sumber: PhpMyAdmin)

\subsection{Definisi Adobe Dreamweaver CS6}

Definisi Adobe Dreamweaver CS6 Menurut Komputer (2013:2)yang dikutip Ita dalam Tugas Akhir menyatakan bahwa: "Adobe Dreamweaver merupakan program editor halaman web (web page) keluaran Adobe System yang dulu dikenal sebagai Macromedia Dreamweaver keluaran Macromedia. Aplikasi ini banyak digunakan oleh pengembang web karena fitur-fiturnya yang menarik dan kemudian penggunanya. Versi terakhir Macromedia Dreamweaver sebelum Macromedia dibeli oleh Adobe System yaitu versi 8 . Versi terakhir Dreamweaver keluaran Adobe System adalah versi 12 yang ada dalam Adobe Creative Suite 6 (serin disingkat Adobe CS6)". Pada dreamweaver CS6, terdapat kemampuan bukan hanya sebagai software untuk desain web saja tetapi juga untuk menyunting kode serta pembuatan aplikasi web dengan menggunakan berbagai bahasa pemograman web, antara lain: $H T M L$, ColdFusion, PHP, CSS, JavaScript dan $X M L$. Aplikasi ini disertakan fitur lebih canggih seperti realtime syntax checking dan kode introspection yang menghasilkan petunjuk kode untuk membantu pengguna dalam menulis kode. Tata letak tampilan Designer memfasilitasi desain cepat dan pembuatan kode seperti kemungkinan pengguna dengan cepat membuat tata letak dan manipulasi HTML. Dreamweaver memiliki fitur browser yang terintegrasi untuk melihat halaman web yang dikembangkan dijendela pratinjau program tersendiri agar content memungkinkan untuk terbuka diweb browser yang telah ter-install. Berikut ini adalah tampilan halaman Welcome Screen dari Dreamweaver CS6 seperti Gambar 2.3 


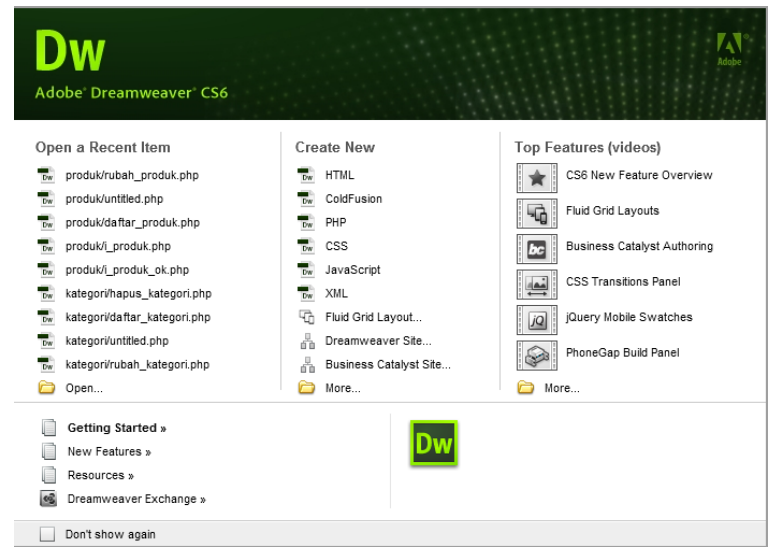

Gambar 2.3 Tampilan halaman Welcome dari Dreamweaver CS6

(Sumber: Dreamweaver CS6)

\subsection{Web Browser}

Definisi Web Browser menurut Anamisa (2011:8) Web browser merupakan software yang digunakan untuk menampilkan informasi dari server web. Bagaimana halaman web yang dibuat ditampilkan sangat tergantung pada web engine yang digunakan masing-masing browser. Semua jenis web browser yang ada saat ini mengikuti standarisasi yang dibuat oleh World Wide Web Consotium (W3C) yang merupakan badan independen yang mengurus semua hal yang berkaitan dengan web dunia. Berikut adalah contoh web browser yang cukup populer beserta web engine yang digunakan:

Web Engine WebKit: Safari, Google Chroom

Web Engine Trident: Microsoft Internet Explorer, Maxthon.

Web Engine Gecko: Mozila Firefox.

Web Engine Presto: Opera.

Berikut ikon-ikon dari beberapa browser:
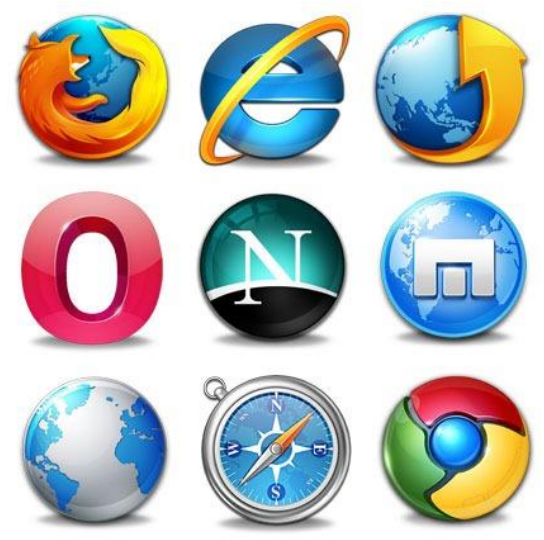

Gambar 2.4 Tampilan ikon-ikon browser (Sumber: http://hautesecure.com/wpcontent/uploads/2015/09/Web-Browser-

Features-You-Should-Know-About.jpg )

\subsection{Definisi MySQL}

MySQL adalah program database yang mampu mengirim dan menerima data dengan sangat cepat dan multi-user. MySQL memiliki dua bentuk lisensi, yaitu free software dan shareware. MySQL yang free software bebas digunakan untuk keperluan pribadi atau usaha tanpa harus membeli atau membayar lisensi, yang berada di bawah lisensi GNU/GPL (general public license). Menurut Nugroho (2005:1) "MySQL adalah sebuah program database server yang mampu menerima dan mengirimkan datanya dengan sangat cepat, multi user serta menggunakan perintah standar SQL (Structured Query Language)". Penulis dapat menarik kesimpulan dari definisi para ahli diatas, bahwa MySQL adalah sebuah program database server yang mampu menerima dan mengirimkan datanya sangat terkenal dan banyak digunakan untuk membangun aplikasi web

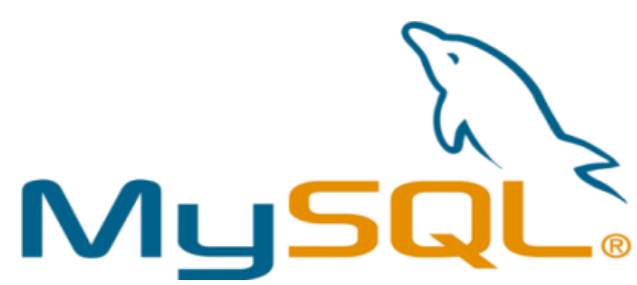

Gambar 2.5 Logo database MySQL 
(Sumber: $\quad$ http://i-3.co.id/wpcontent/uploads/2016/12/mysql.jpg)

\subsection{Definisi Basis Data}

Menurut Anamisa (2011:145) menyebutkan basis data adalah "sekumpulan informasi yang diatur agar mudah dicari." Menurut Nugroho (2005) Basis Data adalah "Komponen utama dalam membangun sebuah sistem yang menyangkut pendokumentasian data kedalam seduah database."

Berdasarkan definisi-definisi para ahli, maka penulis memberikan kesimpulan bahwa basis data adalah sebuah kumpulan yang terorganisasi yang disimpan secara terorganisasi agar mudah melakukan penyimpanan, dimanipulasi dan dipanggil oleh pengguna.

\subsection{Definisi Data Flow Diagram (DFD)}

Menurut Hartono (2005:700) yang dikutip podo dalam tugas akhir DFD adalah:

"DFD sering digunakan untuk menggambarkan suatu sistem yang telah ada atau sistem baru yang akan dikembangkan secara logika tanpa mempertimbangkan lingkungan fisik dimana data tersebut mengalir (misal lewat telpon, surat dan sebagainya) atau lingkungan fisik dimana data tersebut akan disimpan (misalnya file kartu, microfiche, hard disk, tape, diskette dan lain sebagainya)."

Kelebihan DFD yaitu dapat menggambarkan arus data di dalam sistem dengan struktur jelas. Lebih lanjut DFD juga merupakan dokumentasi dari sistem yang baik.

Menurut Hartono (2005:700) "Analisi \& Desain Sistem Informasi: Pendekatan Terstruktur", ada beberapa simbol yang digunakan di DFD untuk mewakili yaitu :

Kesatuan Luar (External Entity)

Kesatuan luar (external entity) merupakan kesatuan (entity) di lingkungan luar sistem yang dapat berupa orang, organisasi atau sistem lainnya yang berada di lingkungan luarnya yang akan memberikan input atau menerima output sistem.

\subsection{Arus Data (Data Flow)}

Arus data mengalir diantara proses (process), simpanan data (data store) dan kesatuan luar (external entity). Arus data menunjukkan arus data dari data yang dapat berupa masukan untuk sistem atau hasil dari proses sistem.

Proses (Process)

Suatu proses adalah kegiatan atau kerja yang dilakukan oleh orang, mesin atau komputer dari hasil suatu arus data yng masuk ke dalam proses untuk dihasilkan arus data yang akan keluar dari proses.

\subsection{Simpanan Data (Data Store)}

Simpanan data (data store) merupakan simpanan dari data yang dapat berupa file atau database pada sistem komputer.

Masing-masing akan diberi lambang untuk membedakan satu sama lain. Dapat dilihat pada tabel

\subsection{Didalam DFD}

Terdapat 3 level, yaitu:

Diagram Konteks

Digram konteks adalah diagram yang menggambarkan suatu lingkaran besar yang dapat mewakili seluruh proses yang terdapat di dalam suatu sistem.

Diagram Nol (diagram level-1)

Diagaram Nol atau diagraM level-1 adalah diagaram yang menggambarkan suatu lingkaran besar yang mewakili lingkaranlingkaran kecil yang ada didalmnya. DFD level-1 merupakan pemecahan dari diagram konteks.

Diagram R inci

Diagram rinci adalah diagram yang menguraikan proses apa saja yang ada didalam diagram Nol. 


\subsection{Definisi Entity Relational Diagram (ERD)}

Menurut Kadir (2009:30) model ER adalah "suatu model yang digunakan untuk mengambarkan data dalm bentuk,entitas, atribut dan hubungan antarentitas."

Menurut Ladjamudin (2012:50) yang dikutip Kalsum dkk(2014:51) Struktur yang mendasari suatu basis data adalah model data yang merupakan kumpulan alat-alat konseptual untuk mendeskripsikan data, relasi data, data semantik dan batasan konsistensis. Entity relationship (ERD) data model didasarkan pada persepsi terhadap dunia nyata yang tersusun atas kumpulan objek-objek dasar yang disebut entitas dan hubungan antar objek. Entitas adalah suatu atau objek dalam dunia nyata yang dapat dibedakan dari objek lain. Sebagai contoh masing-masing motor adalah entitas dan konsumen dapat pula diangap sebagai entitas. Berdasarkan definisi-definisi para ahli, penulis menyimpulkan bahwa ERD adalah simbol-simbol grafis yang digunakan untuk mendeskripsikan hubungan antar penyimpanan yang dikembangkan.

Notasi dan Simbol yang Digunakan Dalam ERD

\subsection{Entitas}

Entitas adalah objek data prinsip tentang informasi yang dikumpulkan. Entitas pada umumnya berupa konsep yang bisa dikenal, baik konkret maupun abstrak, seperti orang, tempat, benda, atau peristiwa yang memiliki keterkaitan terhadap basis data.

Atribut

Atribut menguraikan entitas di mana mereka dihubungkan.

Contoh: Entitas Mahasiswa memiliki atribut-atribut: NPM, Nama, Prodi,

Relasi

Relasi adalah hubungan yang terjadi antar suatu atau lebih entitas.Dapat memiliki atribut dimana terjadi transaksi yang menghasilkan suat u nilai tertentu.

Contoh: entitas Mahasiswa dengan NPM "14410064", dengan Nama: "Rima Pratiwi" mengambil Mata Kuliah "Sistem Basis Data".

Adapun simbol dari ERD menurut adalah seperti tabel 2.2:

Tabel 2.2Simbol ERD Sumber: (Al Fatta 2007:124)

\begin{tabular}{|l|l|}
\hline Simbol & Keterangan \\
\hline & $\begin{array}{l}\text { Persegi Panjang } \\
\text { Sebagai entitas }\end{array}$ \\
\hline & $\begin{array}{l}\text { Oval } \\
\text { Sebagai atribut }\end{array}$ \\
\hline
\end{tabular}

\subsection{Pemetaan Kardinalitas Entity Relation Diagram (ERD)}

Menurut Ichwan menyatakan, "Derajat Relasi/Kardinalitas menunjukkan jumlah maksimum suatu entitas dapat berelasi dengan entitas lain. Adapun kardinalitas yang dapat terjadi antara entitas adalah sebagai berikut:

Untuk suatu himpunan relasi biner $\mathrm{R}$ antara himpunan entitas A dan B, harus salah satu dari berikut:

One-to-one, sebuah entitas pada A berhubungan dngan paling banyak satu entitas pada B dan sebuah entitas pada B berhubungan dengan paling banyak satu entitas pada A.

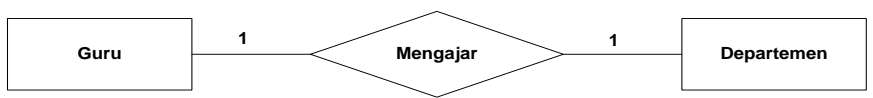

Gambar 2.6 Hubungan One-to-one 
One-to-Many, sebuah entitas pada A berhubungn dengan nol atau lebih entitas pada B. Sebuah entitas pada B dapat dihubungkan dengan paling banyak satu entitas pada $\mathrm{A}$.

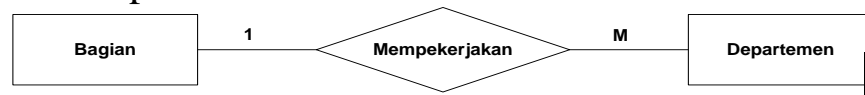

Gambar 2.7 Hubungan One-to-Many

Many-to-One, sebuah entitas pada A berhubungan dengan paling banyak satu entitas pada B. Sebuah entitas pada B dapat dihubungkan dengan nol atau lebih entitas pada A.

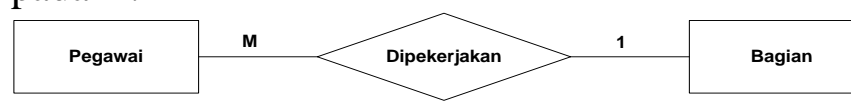

Gambar 2.8 Hubungan Many-to-One

Many-to-Many, sebuah entitas pda A berhubungan dengan nol atau lebih entitas pada B dan sebuah entitas pada B dapat dihubungkan nol atau lebih entitas pada A.

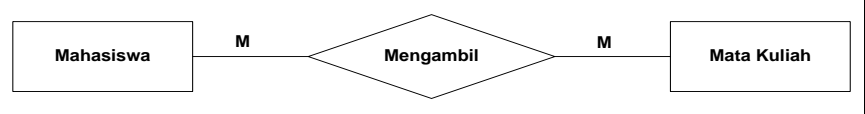

Gambar 2.9 Hubungan Many-to-Many

\subsection{Definisi Bagan Alir (Flowchart)}

Menurut Hartono (2005:795) menyatakan,"Bagan alir (flowchart) adalah bagan (chart) yang menunjukkan alir (flow) di dalam program atau prosedur sistem secara logika. Bagan alir digunakan terutama untuk alat bantu komunikasi dan untuk dokumentasi". Menurut Hartono (2005:796) ada lima macam bagan alir, yaitu:

\section{Bagan Alir Sistem (System Flowchart)}

Bagan alir sistem merupakan bagan yang menunjukkan arus pekerjaan secara keseluruhan dari sistem. Bagan ini menjelaskan urutan dari prosedur-prosedur yang ada di dalam sistem. Bagan alir sistem menunjukkan apa yang dikerjakan di sistem.
Untuk menggambarkan bagan alir sistem ini, digunakan simbol-simbol seperti tabel 2.3:

Tabel 2.3 Simbol Bagan Alir Sistem (Sumber: Hartono 2005:796)

\begin{tabular}{|c|c|c|}
\hline Simbol & Nama & Fungsi \\
\hline & Flow Symbol & $\begin{array}{l}\text { Menghubungkan } \\
\text { antara simbol satu } \\
\text { dengan simbol } \\
\text { yang lain. }\end{array}$ \\
\hline & $\begin{array}{l}\text { Connector } \\
\text { Symbol }\end{array}$ & $\begin{array}{l}\text { Penghubung } \\
\text { proses dalam } \\
\text { lembar/halaman } \\
\text { yang sama. }\end{array}$ \\
\hline & $\begin{array}{l}\text { Connector } \\
\text { Symbol }\end{array}$ & $\begin{array}{l}\text { Penghubung } \\
\text { proses dalam } \\
\text { lembar/halaman } \\
\text { yang berbeda. }\end{array}$ \\
\hline & $\begin{array}{l}\text { Proccesing } \\
\text { Symbol }\end{array}$ & $\begin{array}{l}\text { Menunjukan } \\
\text { pengolahan data } \\
\text { yang dilakukan } \\
\text { komputer. }\end{array}$ \\
\hline & $\begin{array}{l}\text { Manual } \\
\text { Operation } \\
\text { Symbol }\end{array}$ & $\begin{array}{l}\text { Melakukan } \\
\text { pengolahan data } \\
\text { yang dilakukan } \\
\text { manual. }\end{array}$ \\
\hline & $\begin{array}{l}\text { Numerical } \\
\text { Symbol }\end{array}$ & $\begin{array}{l}\text { File non-komputer } \\
\text { yang diarsip urut } \\
\text { angka (numerical) }\end{array}$ \\
\hline & $\begin{array}{l}\text { Alphabetical } \\
\text { Symbol }\end{array}$ & $\begin{array}{l}\text { File non-komputer } \\
\text { yang diarsip urut } \\
\text { huruf } \\
\text { (alphabetical) }\end{array}$ \\
\hline & $\begin{array}{l}\text { Cronological } \\
\text { Symbol }\end{array}$ & $\begin{array}{l}\text { File non-komputer } \\
\text { yang diarsip urut } \\
\text { tanggal } \\
\text { (cronological) }\end{array}$ \\
\hline & $\begin{array}{l}\text { Decision } \\
\text { Symbol }\end{array}$ & $\begin{array}{l}\text { Pemilihan proses } \\
\text { berdasarkan } \\
\text { kondisi. }\end{array}$ \\
\hline & $\begin{array}{l}\text { Display } \\
\text { Symbol }\end{array}$ & $\begin{array}{l}\text { Menyatakan } \\
\text { peralatan output } \\
\text { yang digunakan. }\end{array}$ \\
\hline & $\begin{array}{l}\text { Stored Data } \\
\text { Symbol }\end{array}$ & $\begin{array}{l}\text { Input yang berasal } \\
\text { dari disk atau } \\
\text { disimpan ke dalam } \\
\text { disk. }\end{array}$ \\
\hline & $\begin{array}{l}\text { Magnetic Tape } \\
\text { Unit Symbol }\end{array}$ & $\begin{array}{lr}\text { Input yang berasal } \\
\text { dari pita magnetik } \\
\text { atau } & \text { output } \\
\text { disimpan ke pita } \\
\text { magnetik. }\end{array}$ \\
\hline
\end{tabular}




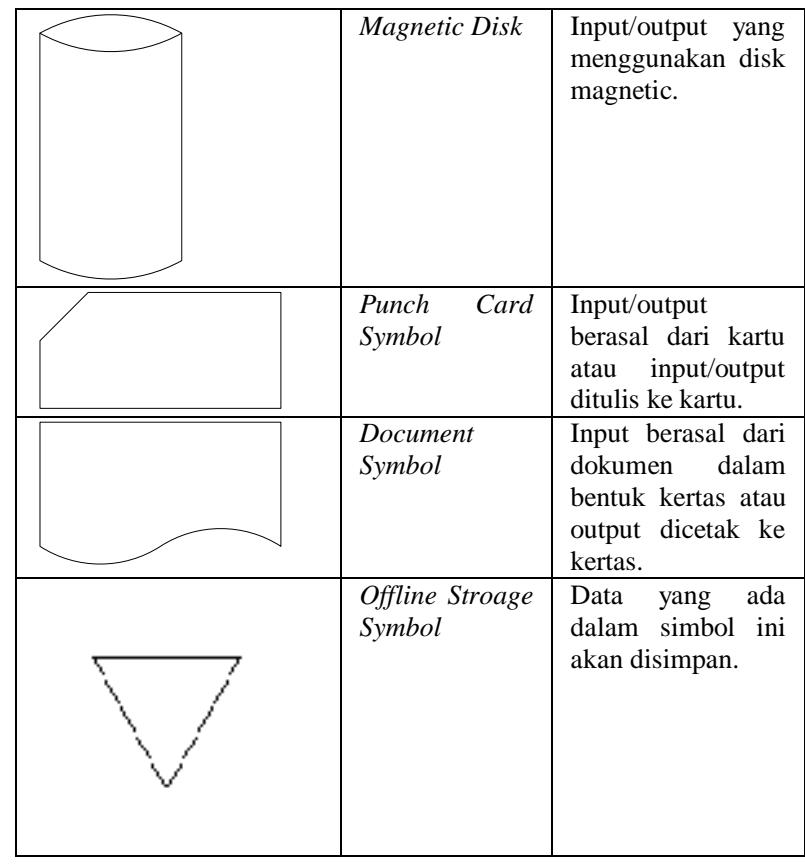

\subsection{Bagan Alir Dokumen (Document Flowchart)}

Bagan alir dokumen (document flowchart) merupakan bagan alir yang menunjukkan arus dari laporan dan formulir termasuk tembusan-tembusannya. Bagan alir dokimen ini menggunkan simbol-simbol yang sama dengan yang digunakan di dalam bagan alir sistem.

Bagan Alir Skematik (Schematic Flowchart) Bagan alir skematik merupakan bagan alir yang mirip dengan bagan alir sistem, yaitu untuk menggambarkan prosedur di dalam sistem. Perbedaannya adalah bagan alir skematik selain menggunakan simbolsimbol bagan alir sistem, juga menggunakan gambar-gambar komputer dan peralatan lainnya yang digunakan

\section{Bagan Alir Program (Program Flowchart)}

Bagan alir program merupakan bagan yang menjelaskan secara rinci langkah-langkah dari proses program. Bagan alir program dibuat dari derivikasi bagan alir sistem. Bagan alir program dibuat dengan menggunakan simbol-simbol seperti tabel 2.5:

Tabel 2.4 Simbol Bagan Alir Program (Sumber: Hartono 2005:802)

\begin{tabular}{|c|c|c|}
\hline Simbol & Nama & Fungsi \\
\hline & $\begin{array}{l}\text { Input } \\
\text { Output } \\
\text { Symbol }\end{array}$ & $\begin{array}{l}\text { Menyatakan } \\
\text { input/output. }\end{array}$ \\
\hline & $\begin{array}{l}\text { Proccesing } \\
\text { Symbol }\end{array}$ & $\begin{array}{l}\text { Menunjukan } \\
\text { pengolahan } \\
\text { data yang } \\
\text { dilakukan } \\
\text { komputer. }\end{array}$ \\
\hline & $\begin{array}{l}\text { Flow Line } \\
\text { Symbol }\end{array}$ & $\begin{array}{l}\text { Untuk } \\
\text { menunjukkan } \\
\text { arus dari proses }\end{array}$ \\
\hline & $\begin{array}{l}\text { Connector } \\
\text { Symbol }\end{array}$ & $\begin{array}{l}\text { Penghubung } \\
\text { proses dalam } \\
\text { lembar/halama } \\
\text { n yang sama. }\end{array}$ \\
\hline & $\begin{array}{l}\text { Connector } \\
\text { Symbol }\end{array}$ & $\begin{array}{l}\text { Penghubung } \\
\text { proses dalam } \\
\text { lembar/halama } \\
\text { n yang berbeda. }\end{array}$ \\
\hline & $\begin{array}{l}\text { Decision } \\
\text { Symbol }\end{array}$ & $\begin{array}{l}\text { Pemilihan } \\
\text { proses } \\
\text { berdasarkan } \\
\text { kondisi. }\end{array}$ \\
\hline & $\begin{array}{l}\text { Predifined } \\
\text { Procces } \\
\text { Symbol }\end{array}$ & $\begin{array}{l}\text { Pelaksanaan } \\
\text { suatu } \\
\text { bagian/prosedu } \\
\text { r. }\end{array}$ \\
\hline & $\begin{array}{l}\text { Preparatio } \\
\text { n Symbol }\end{array}$ & $\begin{array}{l}\text { Mempersiapka } \\
\mathrm{n} \text { penyimpanan } \\
\text { yang akan } \\
\text { digunakan } \\
\text { sebagai tempat } \\
\text { pengelolahan } \\
\text { didalam } \\
\text { stroage. }\end{array}$ \\
\hline & $\begin{array}{l}\text { Terminato } \\
\text { r Symbol }\end{array}$ & $\begin{array}{l}\text { Untuk } \\
\text { permulaan } \\
\text { (start) dan } \\
\text { akhir (stop) } \\
\text { suatu kegiatan. }\end{array}$ \\
\hline
\end{tabular}

\subsection{Bagan Alir Proses (Procces Flowchart)}

Bagan alir program berguna bagi analis sistem untuk menggambarkan proses dalam 
suatu prosedur. Bagan alir proses menggunakan lima buah simbol seperti tabel 2.4:

Tabel 2.5 Simbol Bagan Alir Proses (Sumber: Hartono 2006:806)

\begin{tabular}{|c|c|}
\hline Simbol & Fungsi \\
\hline & $\begin{array}{lll}\begin{array}{l}\text { Menunjukkan } \\
\text { (operation) }\end{array} & \text { suatu } & \text { operasi } \\
\end{array}$ \\
\hline & $\begin{array}{l}\text { Menunjukkan suatu pemindahan } \\
\text { (movement) }\end{array}$ \\
\hline & $\begin{array}{l}\text { Menunjukkan suatu penyimpanan } \\
\text { (stroage) }\end{array}$ \\
\hline & $\begin{array}{l}\text { Menunjukkan } \\
\text { (inspection) }\end{array}$ \\
\hline & $\begin{array}{l}\text { Menunjukkan suat penundaan } \\
\text { (delay) }\end{array}$ \\
\hline
\end{tabular}

\section{METODE}

Metode penelitian adalah kesatuan tata cara untuk mendapatkan data yang di butuhkan untuk mendapat informasi yang di perlukan dan untuk membatu dalam penyusuna tugas akhir dan memberikan informasi kepada yang belum mengerti, pengunaan tata cara yang di gunakan oleh penulis yaitu:

\section{Studi Lapangan}

Studi lapangan adalah cara pengumpulan data dimana data tersebut di kumpulkan secara langsung untuk mempelajari dan memberikan solusi dari masalah yang dihadapi, adapun studi lapangan yang di gunkan adalah :

\section{$\sqrt{ }$ Wawancara.}

Wawancara adalah metode pengumpulan data dengan cara melakukan wawancara kepada Ibu Anita selaku bidang Administrasi dan keuangan SMP Muhammadiyah Ahmad Dahlan.

$\sqrt{ }$ Pengamatan (Observasi).

Observasi adalah metode pengumpulan data dengan cara melakukan pengamatan secara langsung di SMP Muhammadiyah Ahmad Dahlan.

$\sqrt{ }$ Dokumentasi.
Dokumentasi adalah pengumpulan data dengan mengumpulkan dokumen-dokumen untuk kelengkapan pengumpulan data.

\section{Studi Pustaka}

Studi pustaka adalah metode pengumpulan data dengan cara mengumpulkan dan memperlajari literatur dan buku-buku bacaan lain yang terkait dengan masalah yang di hadapi.

\section{PEMBAHASAN}

Dari penelitian yang dilaksanakan pada Madrasah Aliyah Muhammadiyah Boarding School Kota Metro ditemukan beberapa masalah dalam pembayaran SPP yaitu pencatatan masih konvensional menggunakan buku besar sehingga terdapat kesalahan dalam pencatatan pembayaran SPP, kesulitan dalam pencarian data-data siswa yang membayar di Buku Besar mengurutkan satu persatu untuk mencari dan itu membutuhkan waktu cukup lama, belum adanya sistem yang digunakan dalam pengelolaan administrasi keuangan terutama dalam proses pembayaran SPP siswa, pembuatan laporan data pembayaran SPP Madrasah Aliyah dan Pondok perbulan masih dilakukan dengan Microsoft Excel hal tersebut mengakibatkan memakan waktu dalam pembuatan laporan data pembayaran SPP. Oleh karena itu perlu diadakan sebuah Perancangan sistem informasi pengelolaan administrasi keuangan Madrasah Aliyah Muhammadiyah Boarding School Kota Metro. Dengan menganalisa dan mengevaluasi sistem yang sedang berjalan, pada bab ini penulis akan memberikan usulan yang merupakan Peracangan sistem informasi pengelolaan administrasi keuangan Madrasah Aliyah Muhammadiyah Boarding School terutama dalam pengelolaan pembayaran SPP secara komputerisasi yang diharapkan akan membantu dan mempermudah pekerjaan bendahara Madrasah Aliyah Muhammadiyah Boarding School Metro 
dalam penghitungan dan proses pembuatan laporan per bulan yang cepat.

Perancangan sistem informasi pengelolaan administrasi keuangan Madrasah Aliyah Muhammadiyah Boarding School dalam pembayaran SPP menggunakan bahasa pemograman PHP, database MySQL dan menggunakan aplikasi Adobe Dreamweaver CS6. Data yang diolah merupakan data pembayaran SPP siswa/siswi Madrasah Aliyah Muhammadiyah Boarding School, Pengolahan cetak laporan data pembayaran SPP Madrasah Aliyah Muhammadiyah Boarding School dilakukan 1 bulan sekali dan Pencarian data pembayaran SPP siswa dilakukan berdasarkan NIS siswa/siswi Madrasah Aliyah Muhammadiyah Boarding School.

\subsection{Analisis Kebutuhan Sistem}

Analisis kebutuhan sistem yang diperoleh dari berbagai literatur, proses wawancara dengan petugas SPP maupun sumbersumber lain dari buku berkaitan dengan Peracangan sistem informasi pengelolaan administrasi keuangan Madrasah Aliyah Muhammadiyah Boarding School Analisis kebutuhan sistem yang dibutuhkan meliputi:

Data Masukan (Input).

Data masukan (input) yang diperlukan sebagai bahan pembuatan program pembayaran SPP siswa meliputi data siswa, data jenis pembayaran, data pembayaran SPP, data kelas, dan tabel entry SPP.

Proses (Process).

Bendahara dibantu oleh operator dalam mengelola data siswa, data jenis pembayaran, data pembayaran SPP, data kelas, dan data etry SPP. Kemudian sistem akan menyimpan data tersebut kedalam database yang semuannya sudah berelasi. antara tabel satu dengan tabel yang lain. Sistem ini juga bekerja dalam pencarian data pembayaran SPP berdasarkan NIS, dan mencetak laporan.

Keluaran (output) yang dihasilkan.

Keluaran (output) yang dihasilkan

oleh sistem adalah laporan data pembayaran SPP siswa Madrasah Aliyah dan Pondok 1 bulan sekali.

Berdasarkan analisis kebutuhan sistem, diperoleh sepesifikasi sistem yang akan diimplementasikan ke dalam pengolahan data pembayaran SPP siswa, adapun sepesifikasi yang dibutuhkan meliputi: Dapat menerima input data siswa, data jenis pembayaran, data pembayaran SPP, data kelas, dan data entry SPP secara berelasi antar tabel atau otomatis. Dapat memproses laporan pembayaran SPP Madrasah aliyah dan Laporan SPP Pondok. Dapat mengecek data pembayaran SPP siswa secara lebih cepat dan efektif berdasarkan NIS. Implementasi pada sistem yang penulis buat bagaimana dalam perancangan program pembayaran SPP siswa dapat memudahkan bagi pihak sekolah khusunya bendahara dalam mengolah data pembayaran SPP siswa.

\subsection{Tujuan Dan Kegunaan Perancangan}

Tujuan serta kegunaan dari perancangan sistem pada umumnya untuk memberikan gambaran secara umum tentang sistem yang baru, Tujuan dan Kegunaan Perancangan sebagai berikut:

\subsection{Tujuan Perancangan}

Dalam perancangan suatu program diperlukan beberapa tahap untuk menentukan arah program tersebut. Sama seperti yang penulis lakukan dalam membuat sistem ini, untuk menghasilkan sistem informasi pengelolaan administrasi keuangan Madrasah Aliyah Muhammadiyah Boarding School, untuk megetahui proses 
pencarian data pembayaran SPP Madrasah Aliyah Muhammadiyah Boarding School berdasarkan NIS, untuk mengetahui pengelolaan laporan pembayaran data SPP Madrasah Aliyah Muhammadiyah Boarding School 1 bulan sekali .

\subsection{Kegunaan Perancangan}

Kegunaan perancangan sistem pengelolaan administrasi keuangan madrasah aliyah muhammadiyah terutama dalam pembayaran SPP adalah untuk mempermudah bendahara yang dibantu oleh operator sekolah dalam input data siswa, data jenis pembayaran, data pembayaran SPP, data kelas, untuk mempermudah pembuatan laporan data pembayaran SPP Madrasah Aliyah Muhammadiyah Boarding School, untuk mempemudah dalam pencarian data pembayaran siswa berdasarkan NIS. Perancangan ini diusulkan sebagai masukan yang dapat dipertimbangkan untuk meningkatkan efektifitas kerja.

\section{Gambaran Umum Sistem Yang Diusulkan}

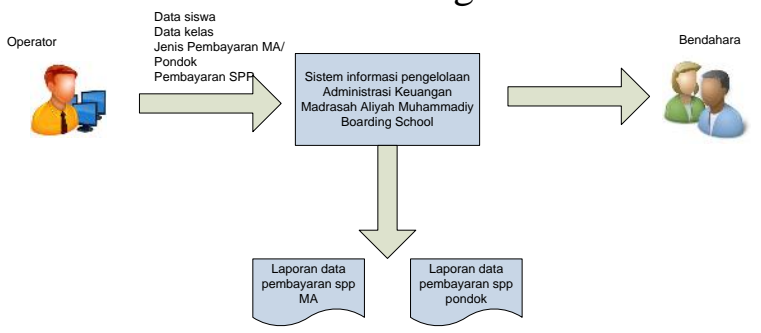

Gambar 4.1 Gambaran Sistem yang diusulkan

Sistem yang diusulkan memiliki beberapa keunggulan dari Perancangan Pengelolaan Administrasi Keuangan Madrasah Aliyah Muhammadiyah Boarding. Sistem yang di usulkan ini telah terkomputerisasi, lebih mudah digunakan dan memperhemat waktu dalam proses pengelolaan data pembayaran SPP siswa, pencarian data pembayaran siswa berdasarkan NIS serta pembuatan laporan per 1 bulan.

\subsection{Rancangan Prosedur Yang Diusulkan}

Pada tahapan perancangan prosedur ini bertujuan untuk menghasilkan Perancangan Pengelolaan Administrasi Keuangan Madrasah Aliyah Muhammadiyah Boarding. Adapun perancangan proses ini sebagai berikut:

\subsection{Bagan Aliran Dokumen (Flowchart)}

Bagan alir (flowchart) merupakan bagan (chart) yang menunjukkan alir (flow) didalam program atau prosedur sistem secara logika. Prosedur sistem yang diajukan yakni:

Bendahara menyerahkan dokumen data pembayaran spp kepada operator untuk diinputkan kedalam sistem. Operator Menginputkan data pembayaran spp siswa kedalam sistem.

Operator mencetak Laporan data pembayaran SPP Madrasah Aliyah dan Pondok 1 bulan sekali diserahkan ke Bendahara untuk dicek, jika laporan sesuai diserahkan kepada kepala sekolah jika tidak maka dikembalikan kepada Operator untuk dicek ulang. Laporan Data pembayaran SPP Madrasah Aliyah Muhammadiyah Boarding School yang sesuai diserahkan kepada kepala sekolah untuk dicek,jika sesuai maka acc/tanda tangan jika tidak maka dikembalikan kembali kepada Operator untuk dicek ulang. Yang dapat dilihat pada tabel 4.1 dibawah ini.

Tabel 4.1 Flowchart pembayaran SPP pada Madrasah Aliyah Muhammadiyah Boarding School Kota Metro yang diusulkan. 
Vol. 01, No. 02, Oktober 2020
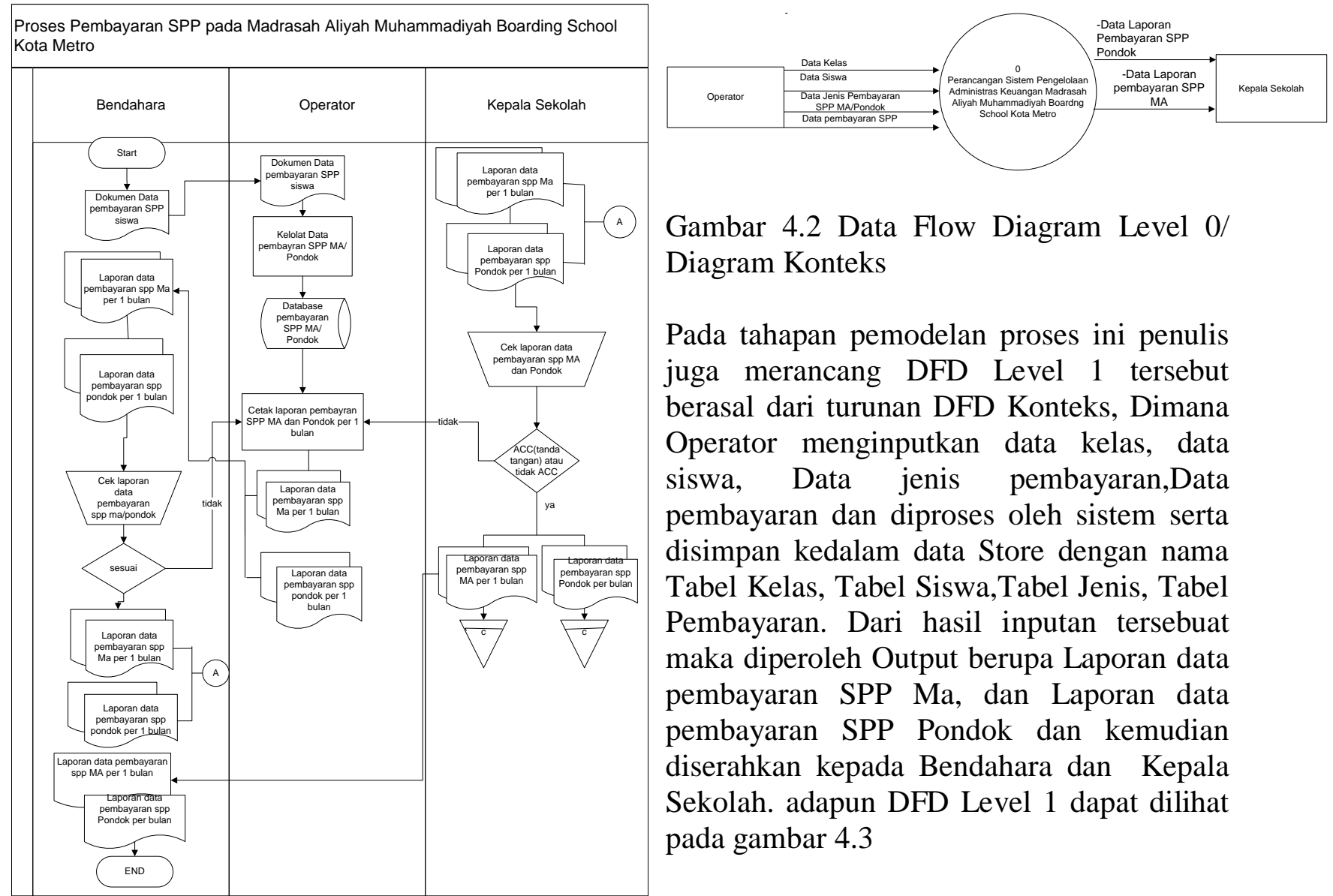

Gambar 4.2 Data Flow Diagram Level 0/ Diagram Konteks

Pada tahapan pemodelan proses ini penulis juga merancang DFD Level 1 tersebut berasal dari turunan DFD Konteks, Dimana Operator menginputkan data kelas, data siswa, Data jenis pembayaran,Data pembayaran dan diproses oleh sistem serta disimpan kedalam data Store dengan nama Tabel Kelas, Tabel Siswa,Tabel Jenis, Tabel Pembayaran. Dari hasil inputan tersebuat maka diperoleh Output berupa Laporan data pembayaran SPP Ma, dan Laporan data pembayaran SPP Pondok dan kemudian diserahkan kepada Bendahara dan Kepala Sekolah. adapun DFD Level 1 dapat dilihat pada gambar 4.3

\section{Data Flow Diagram (DFD)}

\subsection{Data Flow Diagram (DFD)}

DFD berfungsi untuk para pengguna bila ingin megetahui arus data yang terjadi dalam suatu sistem pengolahan data Pembayaran SPP siswa, didalm proses ini operator menginputkan data siswa,data kelas,Data jenis pembayaran SPP MA/Pondok,Data pembayaran kedalam sistem. Dari Hasi Inputan yang telah diproses kedalam sistem menghasilkan Output berupa Data laporan pembayaran SPP MA Dan Laporan Data pembayaran SPP Pondok yang dicek oleh bendahara dan Kepala Sekolah. DFD level 0 dapat dilihat pada gambar 4.2. 
Jurnal Mahasiswa llmu Komputer (JMIK)

Vol. 01, No. 02, Oktober 2020
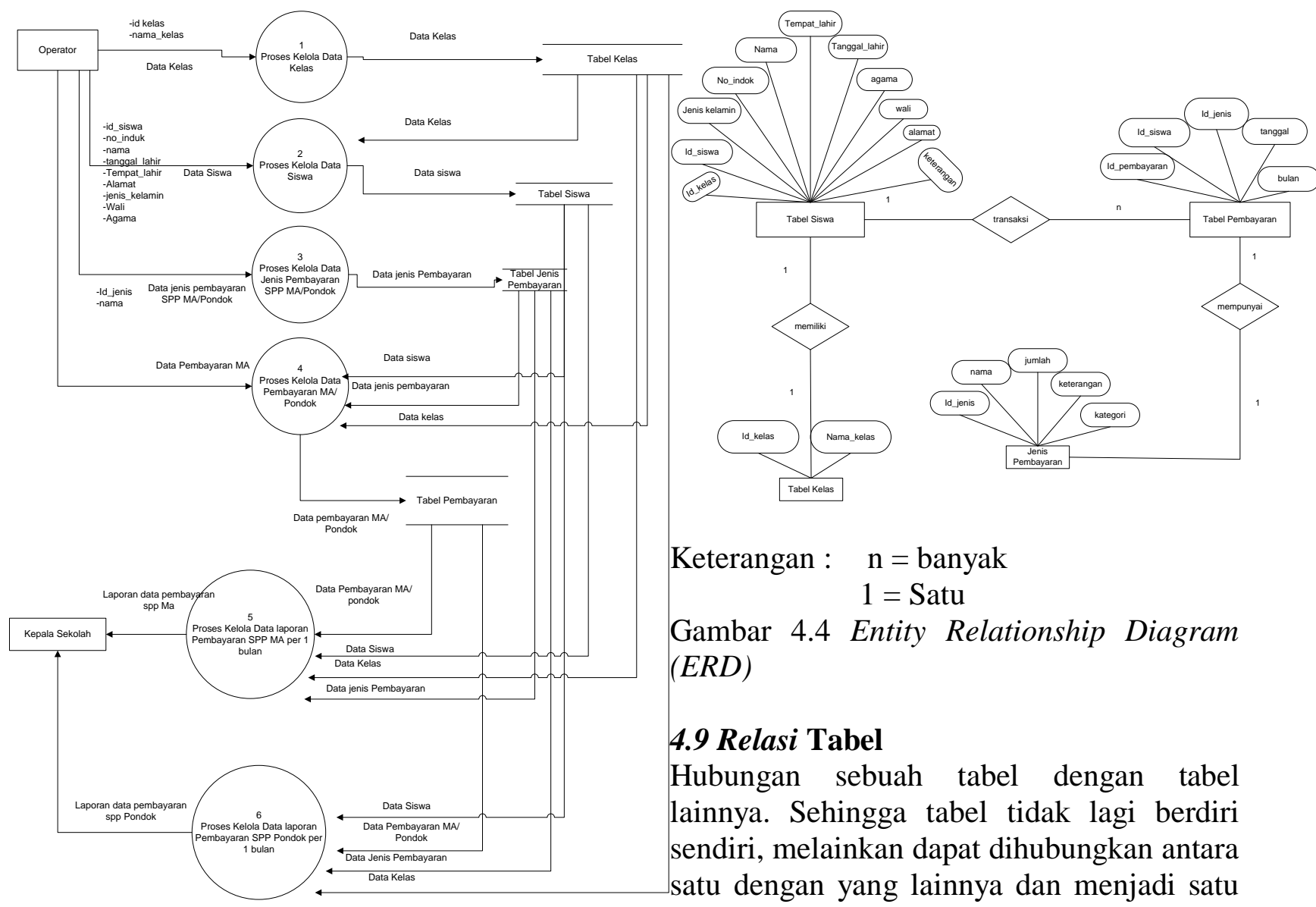

Keterangan : $\mathrm{n}=$ banyak

$$
1=\text { Satu }
$$

Gambar 4.4 Entity Relationship Diagram (ERD)

\subsection{Relasi Tabel}

Hubungan sebuah tabel dengan tabel lainnya. Sehingga tabel tidak lagi berdiri sendiri, melainkan dapat dihubungkan antara satu dengan yang lainnya dan menjadi satu kesatuan. Ada dua buah kolom yang Gambar 4.3 Data Flow Diagram (DFD) Level 1 diperlukan untuk menghubungkan sebuah tabel dengan tabel lainnya. Adapun rancangan database dapat dilihat pada relasi

\subsection{Entity Relationship Diagram (ERD)}

Entity Relationship Diagram (ERD) adalah suatu model jaringan yang menggunakan susunan data yang disimpan dalam sistem secara abstrak. Seperti Gambar 4.4 sebagai berikut : tabel pada Gambar 4.5.

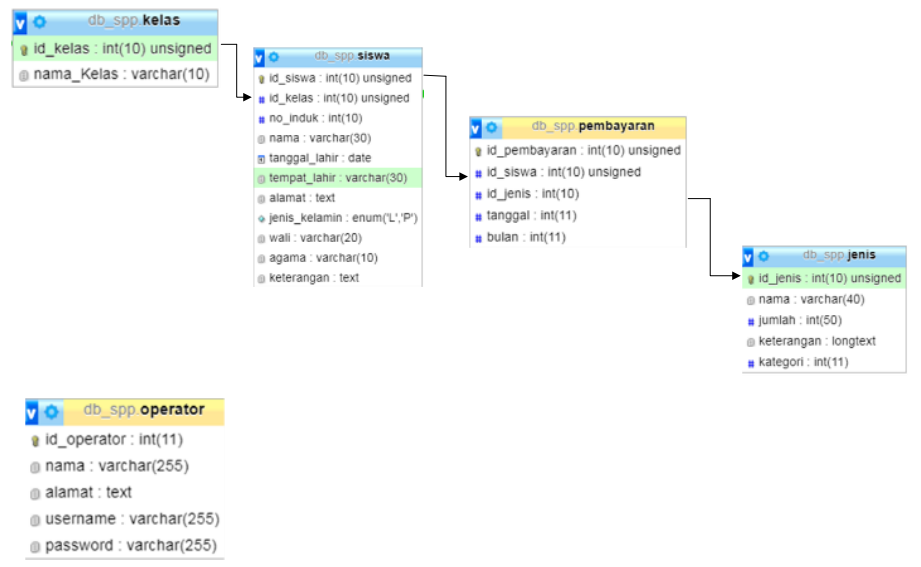

Gambar 4.5 Relasi Tabel

Keterangan : 

$(*)$
$(* *)$
: Primary Key
:Foreign

\subsection{Rancangan File/Basis Data}

Dengan basis data pengguna dapat menyimpan data secara terorganisasi setelah data disimpan, informasi dapat mudah diambil. Cara data disimpan dalam basisdata menentukan seberapa mudah mencari informasi berdasarkan banyak kriterian, datapun harus mudah ditambahkan kedalam basis data, di modifikasi, dan dihapus. Untuk menyimpan data pembayaran SPP siswa diperlukan sebuah database.

Nama database: db_spp

Berikut adalah tabel-tabel dalam database db_spp:

Tabel siswa

Tabel siswa untuk menyimpan data siswa di Madrasah Aliyah Muhammadiyah Boarding School Kota Metro. Berikut adalah stuktur tabel siswa.

Nama Tabel : Siswa

Primary Key : id_siswa

Jumlah Field : 10

Keterangan : Berisi data siswa di Madrasah Aliyah Muhammadiyah Boarding School Kota Metro Tabel 4.2 Tabel Siswa

\begin{tabular}{|l|l|l|l|l|l|}
\hline No & File Field & Type & Length & Primary & Keterangan \\
\hline 1 & Id_siswa & Int & 20 & Yes & $\begin{array}{l}\text { Nomer } \\
\text { siswa }\end{array}$ \\
\hline 2 & Id_kelas & Int & 10 & - & Nomer kelas \\
\hline 3 & N0_induk & Int & 20 & - & Primary key \\
\hline 4 & Nama_siswa & Varchar & 50 & - & $\begin{array}{l}\text { Nama } \\
\text { lengkap } \\
\text { siswa }\end{array}$ \\
\hline 5 & Alamat & Varchar & 50 & - & $\begin{array}{l}\text { Alamat } \\
\text { siswa }\end{array}$ \\
\hline 6 & TTL & Varchar & 50 & - & $\begin{array}{l}\text { Tempat } \\
\text { tanggal lahir } \\
\text { siswa }\end{array}$ \\
\hline 8 & Jenis_kelamin & Varchar & 15 & - & $\begin{array}{l}\text { Jenis } \\
\text { kelamin }\end{array}$ \\
\hline 9 & Wali & Varchar & 15 & - & $\begin{array}{l}\text { Nama } \\
\text { Orang tua }\end{array}$ \\
\hline 10 & Agama & Vaechar & 20 & - & Agama \\
\hline
\end{tabular}

\begin{tabular}{|l|l|l|l|l|l|}
\hline 11 & Keterangan & Varchar & 20 & $\begin{array}{l}\text { Keterangan } \\
\text { untuk siswa } \\
\text { pondok }\end{array}$ \\
\hline
\end{tabular}

Tabel kelas

Tabel kelas berfungsi untuk menyimpan data kelas Madrasah Aliyah Muhammadiyah Boarding School. Berikut adalah struktur tabel kelas.s

Nama Tabel : kelas

Primary Key : id_kelas

Jumlah Field : 2

Keterangan : Berisi data kelas di Madrasah Aliyah Muhammadiyah Boarding School.

Tabel 4.3 Tabel kelas

\begin{tabular}{|l|l|l|l|l|l|}
\hline $\begin{array}{l}\mathrm{N} \\
\mathrm{o}\end{array}$ & File Field & Type & Length & $\begin{array}{l}\text { primar } \\
\mathrm{y}\end{array}$ & Keterangan \\
\hline 1 & id_kelas & Int & 10 & Yes & Primary key \\
\hline 2 & Nama Kelas & Varchar & 30 & - & $\begin{array}{l}\text { Nama kelas } \\
\text { siswa }\end{array}$ \\
\hline
\end{tabular}

Tabel Operator

Tabel Operator berfungsi menyimpan data petugas yaitu operator. Berikut adalah struktur tabel Operator.

Nama Tabel : Operator

Primary Key : id_Operator

Jumlah Field : 5

Keterangan : Berisi data Operator Madrasah Aliyah Muhammadiyah Boarding School Kota Metro.

Tabel 4.4 Tabel Operator

\begin{tabular}{|l|l|l|l|l|l|}
\hline No & File Field & Type & Length & Primary & Keterangan \\
\hline 1 & Id_Operator & Int & 11 & Yes & Primary key \\
\hline 2 & Nama & Varchar & 255 & - & $\begin{array}{l}\text { Nama lengkap } \\
\text { petugas }\end{array}$ \\
\hline 3 & Alamat & Text & & - & Alamat petugas \\
\hline 4 & Username & Varchar & 255 & - & Username \\
\hline 5 & Pasword & Varchar & 255 & - & Password \\
\hline
\end{tabular}

Tabel pembayaran 
Tabel pembayaran berfungsi menyimpan data teransaksi pembayaran. Berikut adalah struktur tabel pembayaran.

Nama Tabel : pembayaran

Primary Key : id_pembayaran

Jumlah Field : 5

Keterangan : Berisi data tentang teransaksi pembayaran antara

siswa dan bendahara Madrasah Aliyah

Muhammadiyah Boarding School.

Tabel 4.5 Tabel Pembayaran

\begin{tabular}{|l|l|l|l|l|l|}
\hline No & File Field & Type & Length & Primary & Keterangan \\
\hline 1 & Id_pembayaran & Int & 10 & Yes & Primary key \\
\hline 2 & Id_siswa & Int & 10 & - & Foreign key \\
\hline 3 & Id_jenis & Int & 10 & - & Foreign key \\
\hline 4 & Tanggal & Date & & - & $\begin{array}{l}\text { Tanggal } \\
\text { pembayaran } \\
\text { siswa }\end{array}$ \\
\hline 5 & Bulan & & 10 & - & Foreign key \\
\hline
\end{tabular}

Tabel jenis bayaran

Tabel jenis bayaran berfungsi menyimpan data kelas siswa di Madrasah Aliyah Muhammadiyah Boarding School Kota Metro. Berikut adalah struktur tabel jenis pembayaran.

Nama Tabel : Jenis

Primary Key : id_jenis

Jumlah Field : 5

Keterangan : Berisi data pembayaran di Madrasah Aliyah Muhammadiyah Boarding School Kota Metro

Tabel 4.6 Tabel jenis bayaran

\begin{tabular}{|l|l|l|l|l|l|}
\hline 5 & Kategori & Int & 11 & & $\begin{array}{l}\text { Kategori } \\
\text { pembayaran }\end{array}$ \\
\hline
\end{tabular}

\subsection{Rancangan Tampilan Program}

Sesuai dengan rancangan yang penulis jabarkan dalam aliran sistem diatas maka rancangan masukan dan keluaran yang penulis rancang adalah sebagai berikut.

Rancangan Login

Rancangan tampilan login pada sistem pengelolaan Administrasi keuangan Madrasah Aliyah Muhammadiyah Boarding School Kota Metro, dapat dilihat pada gambar 4.6.

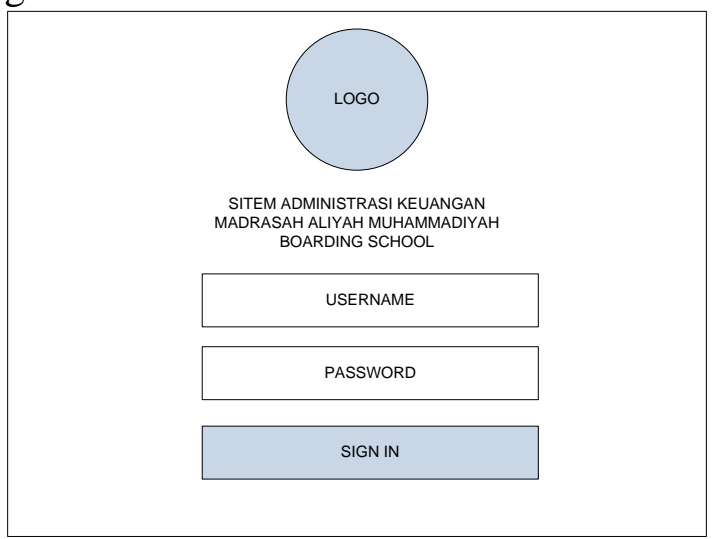

Gambar 4.6 Rancangan Login User

Rancangan pada gambar 4.6 di atas berguna untuk proses awal Operator masuk kedalam sistemdan digunakan untuk pengamanan sistem pembayaran SPP, jika username dan password tidak sesuai dengan yang ada pada database maka akan menampilkan pesan username dan password anda salah hal ini dilakukan untuk menghindari pemalsuan data karena data bersifat sangat rahasia. Fungsi Tombol

\begin{tabular}{|c|c|c|c|c|c|}
\hline $\begin{array}{l}\mathrm{N} \\
\mathrm{o}\end{array}$ & File Field & Type & Length & Primary & $\begin{array}{l}\text { Fung\$i Tombol } \\
\text { Keterangansername : serangkaian huruf yang }\end{array}$ \\
\hline 1 & id_jenis & Int & 10 & Yes & Primary merupakan tanda pengenal untuk masuk dan \\
\hline 2 & Nama & Varchar & 30 & - & $\begin{array}{l}\text { Jenis darmengakses } \\
\text { pembayaPassword : serangkaian huruf atau angka }\end{array}$ \\
\hline 3 & Jumlah & Int & 30 & - & $\begin{array}{l}\text { Nominal } \\
\text { yang dib:yang merupakan sandi untuk dapat }\end{array}$ \\
\hline 4 & Keterangan & longtext & & & $\begin{array}{l}\text { Berisi mengakses.Password } \\
\text { keterang } \\
\text { catatan } \\
\text { tambahasia,sehingarat kita tidak diperkenankan } \\
\text { tamberitahukanya kepada orang lain.ketika }\end{array}$ \\
\hline
\end{tabular}
pengguna memasukan password,maka yang 
terlihat pada tampilan komputer hanya berupa karakter bintang(*)sehingga tidak akan terbaca dalam bentuk angka maupun tulisan. Sign in :Masuk agar dapat mengakses

\subsection{Rancangan Menu Utama}

Rancangan Menu Utama sistem pengelolaan Administrasi keuangan Madrasah Aliyah Muhammadiyah Boarding School Kota Metro dapat dilihat pada gambar 4.7.

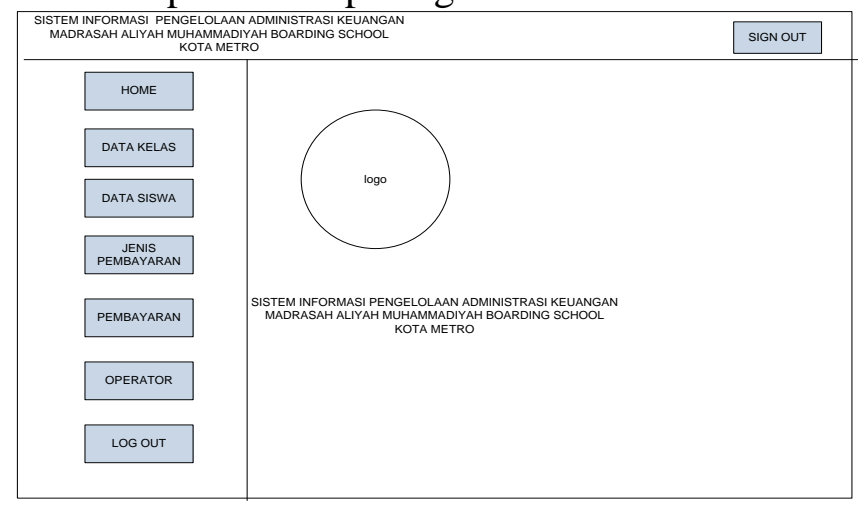

Gambar 4.7. Rancangan Menu Utama

Rancangan menu utama yang berfungsi untuk pengelolaan data pembayaran SPP pada Madrasah Aliyah Muhammadiyah Boarding School Kota Metro terdiri dari Home,Data Kelas,Data Siswa,Jenis Pembayaran,Operator,Log Out.

Rancangan Menu Input Data Kelas

Rancangan menu input siswa berfungsi untuk meninputkan data kelas dapat dilihat pada gambar 4.8.

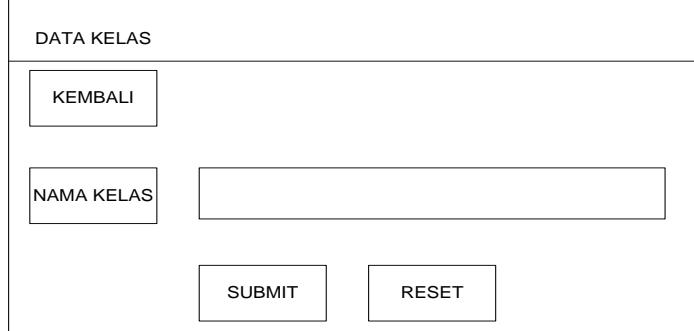

Button Submit : Berfungsi memulai pemrosesan data yang diinput untuk disimpan.

Button Reset : berfungsi untuk mengkosongkan file untuk diulang dalam proses penginputan.

\subsection{Rancangan Menu Input Siswa}

Rancangan menu input siswa yang berfungsi untuk menginputkan biodata siswa. dapat dilihat pada gambar 4.9.

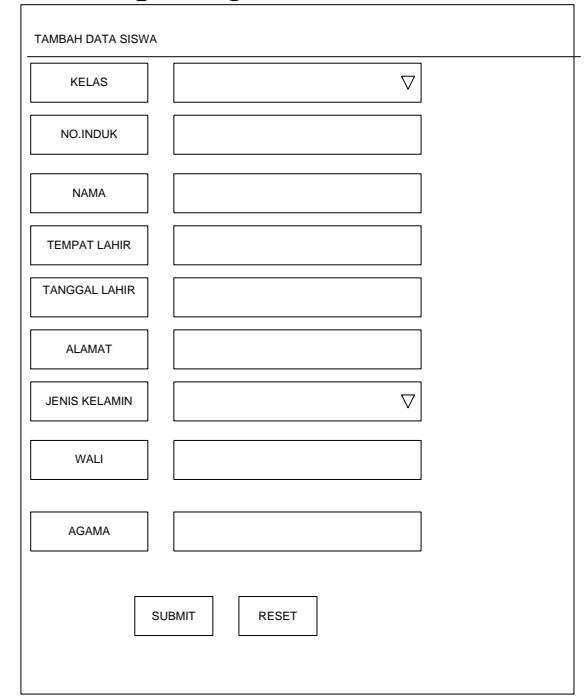

Gambar 4.9. Rancangan Input Siswa

Button Submit : Berfungsi memulai pemrosesan data yang diinput untuk disimpan.

Button Reset : berfungsi untuk mengkosongkan file untuk diulang dalam proses penginputan.

Gambar : check $\downarrow \nabla x$ berfungsi untuk memberikan pilihan kepada user untuk memilih satu dari beberapa pilihan.

\subsection{Rancangan Menu Input Jenis Pembayaran}

Rancangan Input Jenis pembayaran berfungsi untuk menginputkan jenis pembayaran SPP MA dan SPP Pondok. dapat dilihat pada gambar 4.10.

Gambar 4.8. Rancangan Input Kelas 


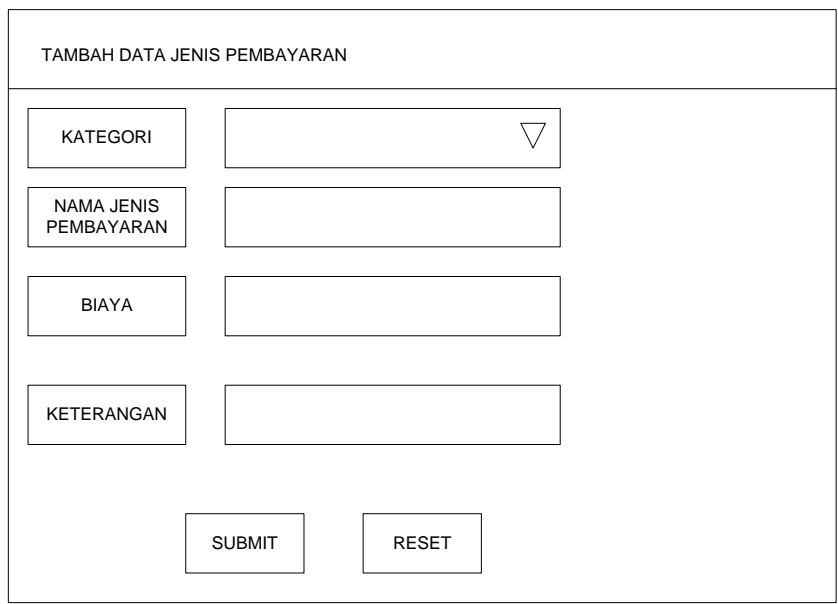

Gambar 4.10. Input Jenis Pembayaran

Button Submit : Berfungsi memulai pemrosesan data yang diinput untuk disimpan.

Button Reset : berfungsi untuk mengkosongkan file untuk diulang dalam proses penginputan.

Gambar : check $\varnothing$ x berfungsi untuk memberikan pilihan kepada user untuk memilih satu dari beberapa pilihan.

\subsection{Rancangan Menu Input Pembayaran}

Rancangan Menu Input Pembayaran berfungsi untuk menginputkan pembayaran dilakuakn oleh siswa. Dapat diihat pada gambar 4.11.

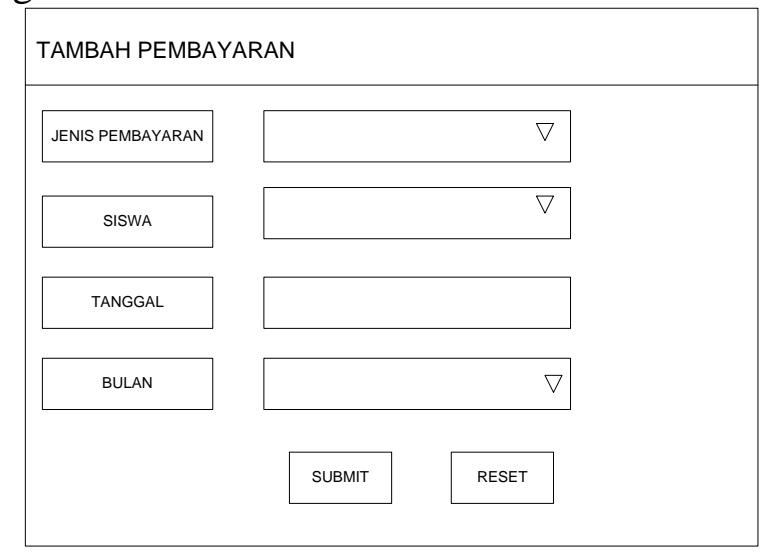

Gambar 4.11. Input Pembayaran
Button Submit : Berfungsi memulai pemrosesan data yang diinput untuk disimpan.

Button Reset : berfungsi untuk mengkosongkan file untuk diulang dalam proses penginputan.

Gambar : check $\nabla \nabla x$ berfungsi untuk memberikan pilihan kepada user untuk memilih satu dari beberapa pilihan.

\subsection{Rancangan Laporan Data pembayaran SPP}

Rancangan Laporan Data pembayaran spp berfungsi untuk melaporkan data pembayran spp. Dapat dilihat gambar 4.12.

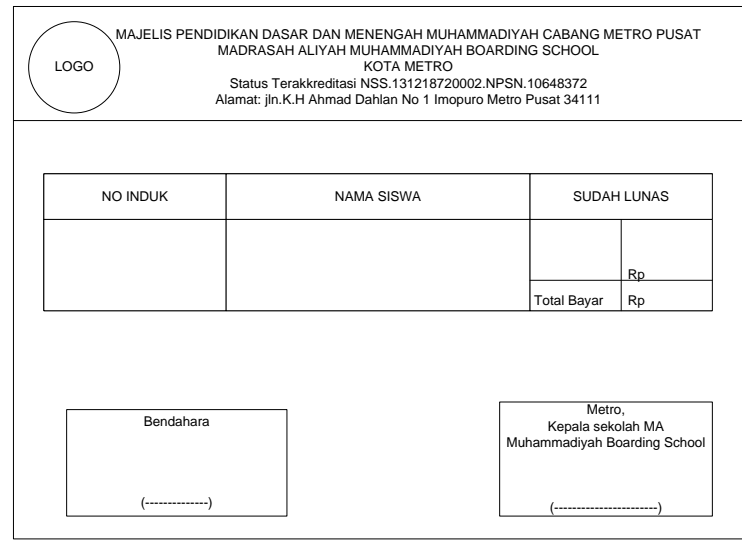

Gambar 4.12 Rancangan Laporan Data pembayaran SPP

\subsection{Hasil Pembahasan Program}

Tampilan Masukan

Tampilan Login

Menu login adalah interface pertama yang dibuka ketika pertama kali diakses oleh operator. Interface menu login ini berfungsi untuk masuk ke interface menu utama. Tampilan interface menu login dapat dilihat pada gambar 4.13. : 


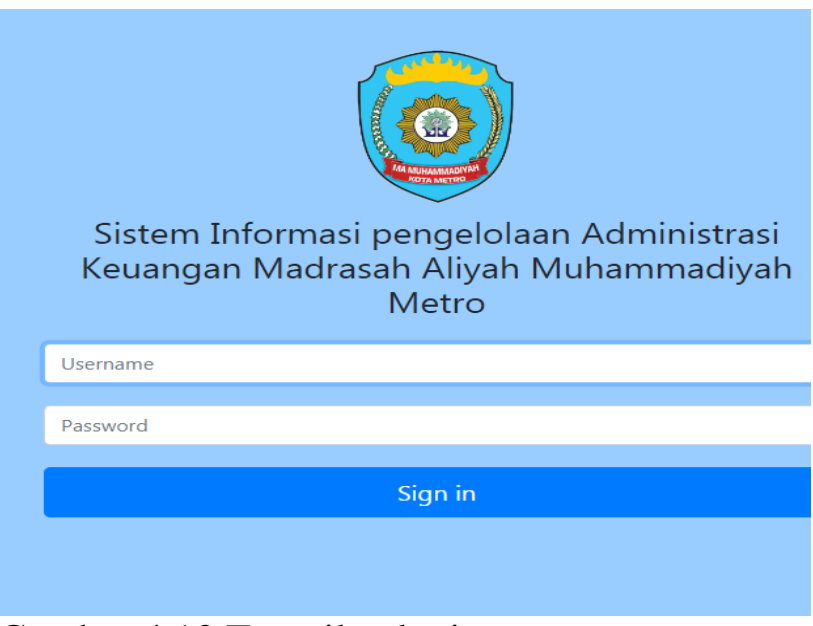

Gambar 4.13 Tampilan login

\subsection{Menu Utama}

Menu utama adalah tampilan setelah login.

Menu utama berisi sub menu. Tampilan menu utama dapat dilihat pada gambar 4.14.

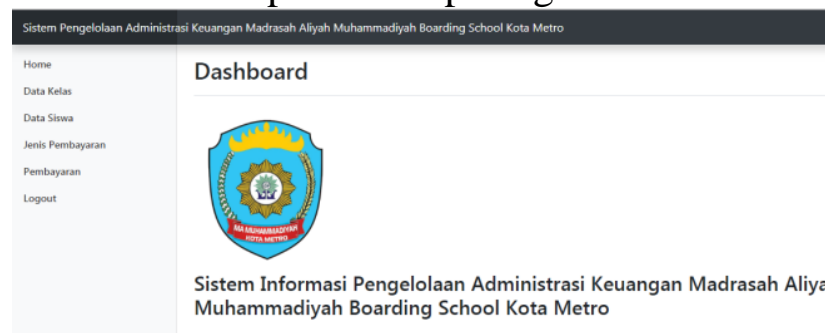

Gambar 4.14 Tampilan Menu Utama

\subsection{Menu Input Kelas}

Menu Input Kelas berfungsi untuk menginputkan kelas. Dapat dilihat pada gambar 4.15.

Data Kelas
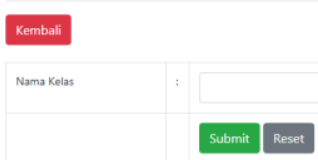

Gambar 4.15 Tampilan input kelas

Button Submit : Berfungsi memulai pemrosesan data yang diinput untuk disimpan.

Button Reset : berfungsi untuk mengkosongkan file untuk diulang dalam proses penginputan.

\subsection{Tampilan Hasil input kelas}

Hasil Data input kelas untuk menampilkan hasil inputan data kelas. Dapat dilihat pada gamba 4.16.

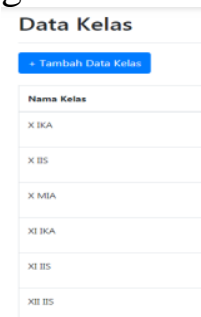

Gambar 4.16 Hasil input Data Kelas

Button ubah : Berfungsi untuk mengubah atau mengedit hasil inputan.

Button Hapus :Menghapus data yang telah diinputkan kedalam sistem.

\subsection{Menu Input Siswa}

Rancangan menu input siswa yang berfungsi untuk menginputkan biodata siswa. Dapat dilihat pada Gambar 4.17.

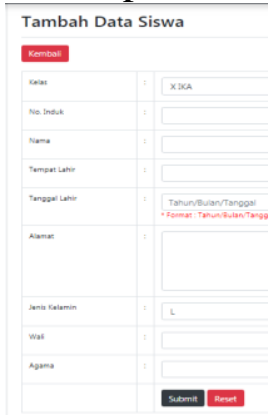

Gambar 4.17 Tampilan Input Siswa

Button Submit : Berfungsi memulai pemrosesan data yang diinput untuk disimpan.

Button Reset : berfungsi untuk mengkosongkan file untuk diulang dalam proses penginputan.

Gambar : check $\nabla$ x berfungsi untuk memberikan pilihan kepada user untuk memilih satu dari beberapa pilihan.

\subsection{Tampilan Hasil Input Data Siswa}

Tampilan input data siswa berfungsi untuk menampilkan hasil inputan data siswa. Dapat dilihat pada Gambar 4.18. 


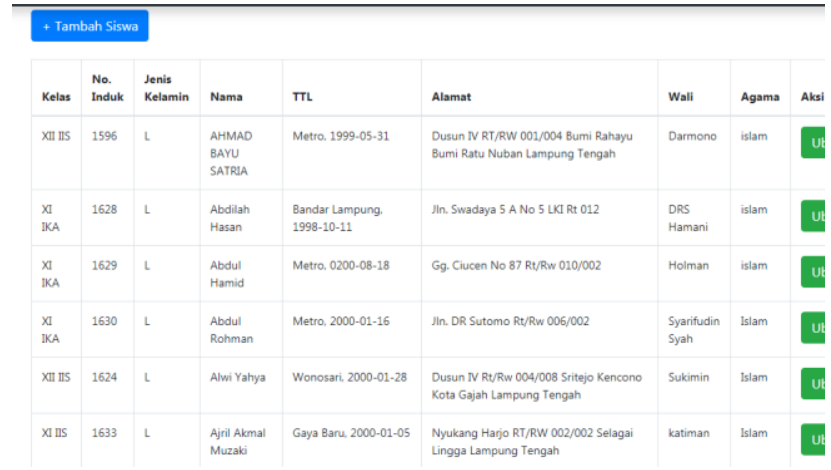

Gambar 4.18 Hasil Tampilan Inputan Data siswa

\subsection{Menu Input Jenis Pembayaran}

Menu Input Jenis Pembayaran berfungsi untuk menginputkan kategori jenis SPP yang akan dibayarkan. Dapat dilihat pada Gambar 4.19.

Tambah Data Jenis Pembayaran

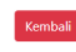

Kategori

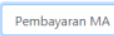

Nama Jenis Pembayaran

Jumlah

\section{sibrit Resect}

Gambar 4.19 Input Jenis Pembayaran

\subsection{Hasil Tampilan Input Jenis Pembayaran}

Hasil input jenis pembayaranberfungsi untuk menampilkan Hasil input jenis kategori pembayaran SPP. Dapat dilihat pada Gambar 4.20.

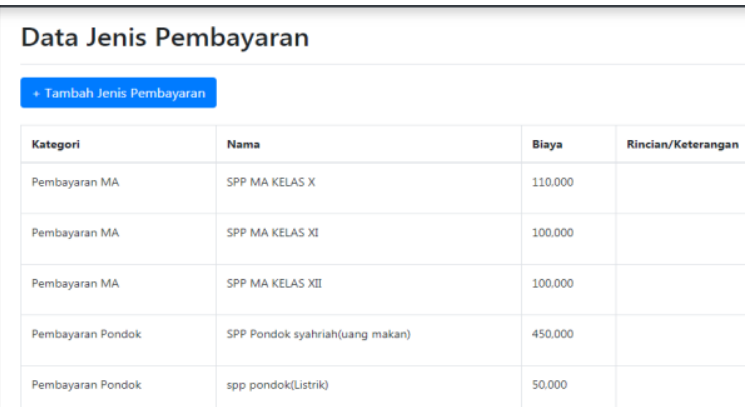

Gambar 4.20 Hasil inputan jenis pembayaran.

\subsection{Menu inputan Pembayaran SPP} Menu inputan Pembayran SPP berfungsi untuk menginputkan transaksi pembayaran SPP yang dilakukan oleh siswa Madrasah aliyah/maupun Pondok. Dapat dilihat pada Gambar 4.21.

Tambah Pembayaran
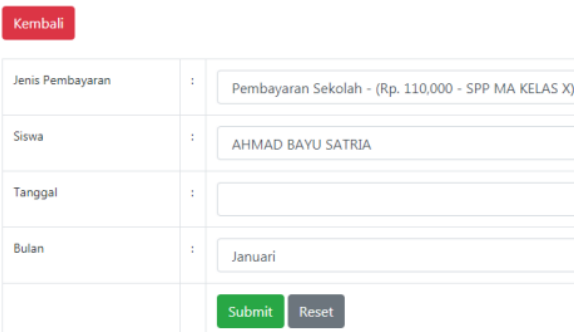

Gambar 4.21. Menu inputan Pembayaran SPP

\subsection{Tampilan Hasil Inputan Pembayaran SPP}

Hasil Tampilan inputan pembayaran SPP berfungsi untuk menampilkan transaksi pembayran SPP Yang telah dibayarkan. Dapat dilihat pada Gambar 4.22.

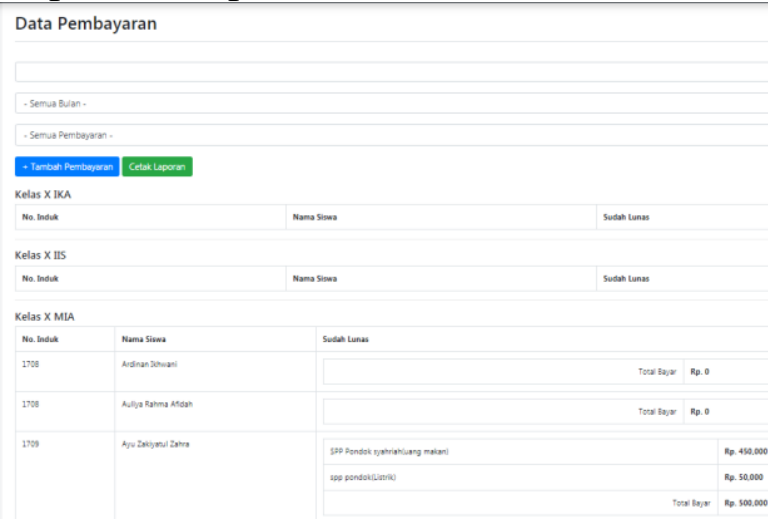

Gambar 4.22. Tampilan Data Pembayaran

\subsection{Tampilan Keluaran}

Tampilan ini berisi laporan data pembayaran SPP Madrasah Aliyah dan laporan data pembayaran Pondok yang telah diproses.

Hasil Tampilan Laporan

Hasil Tampilan Laporan yakni untuk menampilkan laporan data pembayaran spp 
Vol. 01, No. 02, Oktober 2020

MA maupun Pondok perbulan.Dapat dilihat pada Gambar 4.23 untuk laporan pondok. Dan Gambar 4.24 Tampilan laporan Madrasah Aliyah.

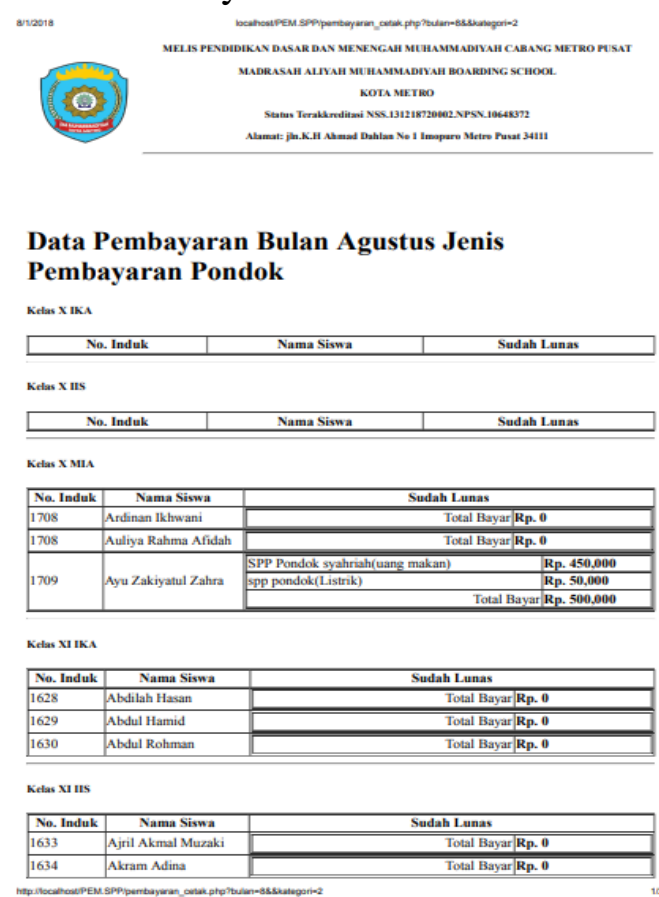

Gambar 4.23 Laporan Data pembayaran SPP Pondok

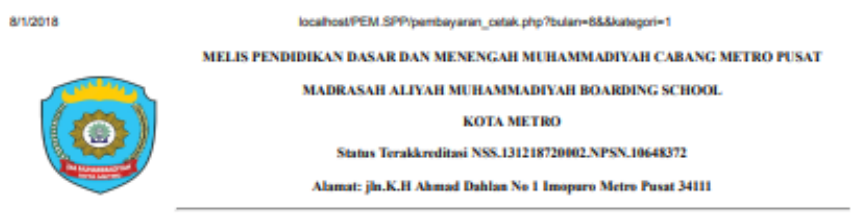

\section{Data Pembayaran Bulan Agustus Jenis Pembayaran Sekolah}

Kelas X IKA

\begin{tabular}{|c|c|c|c|}
\hline \multicolumn{2}{|c|}{ No. Induk } & Nama Siswa & Sudah L.unas \\
\hline \multicolumn{4}{|l|}{ Ketas X IIS } \\
\hline \multicolumn{2}{|c|}{ No. Induk } & Nama Siswa & Sudah Lunas \\
\hline \multicolumn{4}{|l|}{ Kelas X MiA } \\
\hline No. Induk & Nama Siswa & \multicolumn{2}{|c|}{ Sudah L.unas } \\
\hline 1708 & Ardinan Ikhwani & \multicolumn{2}{|c|}{ Total Bayar Rp. 0} \\
\hline 1708 & Auliya Rahma Afidah & \multicolumn{2}{|c|}{ Total Bayar Rp. 0} \\
\hline 1709 & Ayu Zakiyatul Zahra & \multicolumn{2}{|c|}{$\begin{array}{l}\text { Total Bayar } \mathbf{R p . 0} \\
\end{array}$} \\
\hline \multicolumn{4}{|l|}{ Kelas XI IKA } \\
\hline No. Induk & Nama Siswa & \multicolumn{2}{|c|}{ Sudah Lunas } \\
\hline 1628 & Abdilah Hasan & \multicolumn{2}{|c|}{ Total Bayar Rp. 0} \\
\hline \multirow{2}{*}{1629} & \multirow{2}{*}{ Abdul Hamid } & SPP MA KEL_AS XI & Rp. 100,000 \\
\hline & & \multicolumn{2}{|c|}{ Total Bayar Rp. 100,000 } \\
\hline 1630 & Abdul Rohman & \multicolumn{2}{|c|}{$\begin{array}{l}\text { Total Bayar } \mathbf{R p . 0} \\
\end{array}$} \\
\hline \multicolumn{4}{|l|}{ Kelas X1 us } \\
\hline No. Induk & Nama Siswa & & \\
\hline 1633 & Ajril Akmal Muzaki & & $\begin{array}{l}\text { Bayar Rp. } 0 \\
\end{array}$ \\
\hline 1634 & Akram Adina & & Bayar Rp. 0 \\
\hline
\end{tabular}

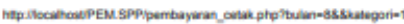

Gambar 4.24 Tampilan laporan Pembayaran SPP Madrasah Aliyah

\subsection{Kelebihan dan Kekurangan Program} Adapun kelebihan dan kekurangan sistem yang telah dirancang adalah sebagai berikut :

Kelebihan Program

$\checkmark$ Dengan menggunakan sistem pengelolaan administrasi keuangan madrasah aliyah muhammadiyah Boarding School mempermudah bendahara yang dibantu oleh operator sekolah dalam input data siswa, data jenis pembayaran, data pembayaran SPP, data kelas. 
Sehingga, tidak perlu bekerja dua kali untuk memindahkan data.

$\sqrt{ }$ Mempemudah dalam pencarian data pembayaran siswa berdasarkan NIS.

$\sqrt{ }$ mempermudah pembuatan laporan data pembayaran SPP Madrasah Aliyah Muhammadiyah Boarding School .

Kekurangan Program

Program yang dirancang oleh penulis jauh dari kata sempurna, kekurangan dari program ini adalah sebagai berikut :

$\sqrt{ }$ Perancangan Sitem Informasi pengelolaan Administrasi Keuangan Madrasah Aliyah Muhammadiyah Boarding School masih dekstop belum dapat diakses secara online.

$\sqrt{ }$ Sistem Ini belum dapat mengelompokan yang mana siswa Madrasah Aliyah dan Siswa Pondok. Untuk memudahkannya dibedakan dalam Keterangan siswa.

\section{KESIMPULAN}

Dari hasil penelitian pada Madrasah Aliyah Muhammadiyah Boarding School Metro dapat di ambil kesimpulan sebagai berikut :

$\sqrt{ }$ Sistem Informasi Pengelolaan data Administrasii Keuangan Madrasah Aliyah Madrasah Aliyah Muhammadiyah Boarding School menggunakan Dreamweaver CS6, bahasa pemrograman PHP dengan menggunakan Database MySQL.

$\checkmark$ Sistem Informasi pengelolaan Administrasi Keuangan Madrasah Aliyah Muhammadiyah Boarding School dapat melakukan pencarian data pembayaran SPP berdasarkan NIS.

$\sqrt{ }$ Sistem yang penulis buat ini dapat mencetak laporan pembayaran SPP Madrasah Aliyah dan Laporan Pembayaran SPP Pondok, dengan lebih cepat dan terperinci 1 bulan sekali.

Saran

Meskipun Sistem ini memiliki beberapa keunggulan dalam pengolahan data pembayaran SPP siswa, namun masih memiliki banyak kekurangan di antaranya sebagai berikut :

$\sqrt{ }$ Dengan sistem yang penulis buat ini diharapkan pada pihak sekolah atau petugas SPP digunakan sehingga dapat membantu dalam pengolahan data pembayaran SPP siswa.

$\sqrt{ }$ Sistem ini belum adanya tahun ajaran otomatis. Harapannya adanya pengembangan selanjutnya.

$\sqrt{ }$ Agar kegiatan yang dilakukan hasilnya maksimum perlu ditingkatkan ketelitian personil untuk menghindari kesalahan.dan perlu adanya tenaga ahli yang menguasai komputer untuk mengolah data pembayaran SPP melalui sistem komputer yang telah dikembangkan. Tenaga ahli yang menguasai komputer untuk mengolah data pembayaran SPP melalui sistem komputer yang telah dikembangkan .

$\sqrt{ }$ Sitem Informasi pengelolaan Administrasi Keuangan Madrasah Aliyah Muhammadiyah Boarding School ini masih berbasis dekstop untuk kedepannya agar ada perubahan supaya bisa diakses secara online dan menjadi lebih baik.

$\sqrt{ }$ Sistem Informasi pengelolaan Administrasi Keuangan Madrasah Aliyah Muhammadiyah agar dilakuakn perawatan sesuai dengan perkembangan Teknologi.

\section{DAFTAR PUSTAKA}

[1]

Anamisa,Rosa,Devie.2011. Pemrograman Basis Data Berbasis Web 
Menggunakan PHP \& MySQL.Yogyakarta:GRAHA ILMU.

[2] Jogiyanto.2005.Analisis Desain.Sistem Informasi.Pendekatan Terstruktur Teori Dan Praktek Aplikasi Bisnis. Yogyakarta: CV.ANDI OFFSET.

[3] Kadir,Abdul.2009. Dasar Perancangan dan implementasi. Yogyakarta:C.V ANDI OFFSET.

[4] Ladjamudin.2012. Sistem Antrian Pada Puskesmas Sukamerindu.Vol.8.No.1.ISSN: $1858-2680$.

[5] Nugroho. Bunafit. 2015. Database Relasional dengan MySQL.Yogyakarta:ANDI OFFSET.

[6]Rizky,Soetomo.2014. Perancangan Sistem Informasi Penerimaan Siswa Baru Berbasis WEB Pada SMK N 6 Muaro Jambi. Vol.8. No.2. ISSN: 1978-8126.

[7] Sidik, Betha. 2014. Perancangan Sistem Informasi Administrasi Keuangan Sekolah Berbasis Multiuser Pada Madrasah Tsanawiyahal Uswah Bergas.Vol.1.No.1.ISSN:3456-789. 